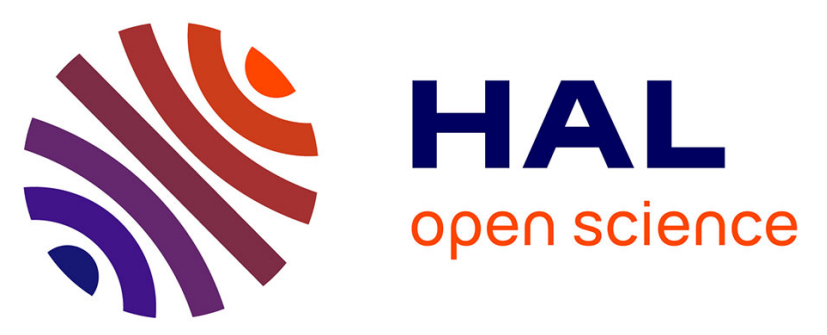

\title{
The AMMA-CATCH Gourma observatory site in Mali : relating climatic variations to changes in vegetation, surface hydrology, fluxes and natural resources
}

Éric Mougin, Pierre Hiernaux, L. Kergoat, Manuela Grippa, Patricia de Rosnay, Franck Timouk, Valérie Le Dantec, Valérie Demarez, François Lavenu, M. Arjounin, et al.

\section{To cite this version:}

Éric Mougin, Pierre Hiernaux, L. Kergoat, Manuela Grippa, Patricia de Rosnay, et al.. The AMMACATCH Gourma observatory site in Mali : relating climatic variations to changes in vegetation, surface hydrology, fluxes and natural resources. Journal of Hydrology, 2009, 375, pp.HYDROL 16662. 10.1016/j.jhydrol.2009.06.045 . ird-00402391

\section{HAL Id: ird-00402391 https://hal.ird.fr/ird-00402391}

Submitted on 7 Jul 2009

HAL is a multi-disciplinary open access archive for the deposit and dissemination of scientific research documents, whether they are published or not. The documents may come from teaching and research institutions in France or abroad, or from public or private research centers.
L'archive ouverte pluridisciplinaire HAL, est destinée au dépôt et à la diffusion de documents scientifiques de niveau recherche, publiés ou non, émanant des établissements d'enseignement et de recherche français ou étrangers, des laboratoires publics ou privés. 


\section{Accepted Manuscript}

The AMMA-CATCH Gourma observatory site in Mali: Relating climatic variations to changes in vegetation, surface hydrology, fluxes and natural resources

E. Mougin, P. Hiernaux, L. Kergoat, M. Grippa, P. de Rosnay, F. Timouk, V. Le Dantec, V. Demarez, F. Lavenu, M. Arjounin, T. Lebel, N. Soumaguel, E. Ceschia, B. Mougenot, F. Baup, F. Frappart, P.L. Frison, J. Gardelle, C. Gruhier, L. Jarlan, S. Mangiarotti, B. Sanou, Y. Tracol, F. Guichard, V. Trichon, L. Diarra, A. Soumaré, M. Koité, F. Dembélé, C. Lloyd, N.P. Hanan, C. Damesin, C. Delon, D. Serça, C. Galy-Lacaux, J. Seghieri, S. Becerra, H. Dia, F. Gangneron, P. Mazzega

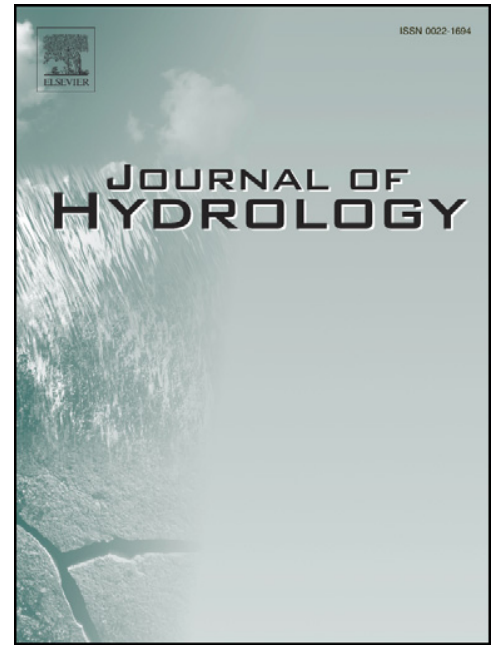

PII:

S0022-1694(09)00382-5

DOI: 10.1016/j.jhydrol.2009.06.045

Reference: HYDROL 16662

To appear in:

Journal of Hydrology

Received Date:

26 March 2009

Revised Date:

10 June 2009

Accepted Date:

25 June 2009

Please cite this article as: Mougin, E., Hiernaux, P., Kergoat, L., Grippa, M., de Rosnay, P., Timouk, F., Dantec, V.L., Demarez, V., Lavenu, F., Arjounin, M., Lebel, T., Soumaguel, N., Ceschia, E., Mougenot, B., Baup, F., Frappart, F., Frison, P.L., Gardelle, J., Gruhier, C., Jarlan, L., Mangiarotti, S., Sanou, B., Tracol, Y., Guichard, F., Trichon, V., Diarra, L., Soumaré, A., Koité, M., Dembélé, F., Lloyd, C., Hanan, N.P., Damesin, C., Delon, C., Serça, D., Galy-Lacaux, C., Seghieri, J., Becerra, S., Dia, H., Gangneron, F., Mazzega, P., The AMMA-CATCH Gourma observatory site in Mali: Relating climatic variations to changes in vegetation, surface hydrology, fluxes and natural resources, Journal of Hydrology (2009), doi: 10.1016/j.jhydrol.2009.06.045

This is a PDF file of an unedited manuscript that has been accepted for publication. As a service to our customers we are providing this early version of the manuscript. The manuscript will undergo copyediting, typesetting, and review of the resulting proof before it is published in its final form. Please note that during the production process errors may be discovered which could affect the content, and all legal disclaimers that apply to the journal pertain. 
42

43

44

\section{The AMMA-CATCH Gourma observatory site in Mali: Relating climatic variations to changes in vegetation, surface hydrology, fluxes and natural resources}

E. Mougin ${ }^{\text {a }}$, P. Hiernaux ${ }^{\text {a }}$, L. Kergoat ${ }^{\text {a }}$, M. Grippa ${ }^{\text {a }}$, P. de Rosnay ${ }^{\text {a }}$, F. Timouk ${ }^{\text {, }}$, V. Le Dantec ${ }^{a}$, V. Demarez ${ }^{a}$, F. Lavenu ${ }^{a}{ }^{\dagger}$, M. Arjounin $^{b}$, T. Lebel ${ }^{b}, N$. Soumaguel $^{\mathrm{c}}$, E. Ceschia ${ }^{\mathrm{a}}$, B. Mougenot ${ }^{\mathrm{a}}$, F. Baup ${ }^{\mathrm{a}}$, F. Frappart ${ }^{\mathrm{a}}$, P.L. Frison ${ }^{\mathrm{d}}$, J. Gardelle $^{a}$, C. Gruhier ${ }^{\mathrm{a}}$, L. Jarlan ${ }^{\mathrm{a}}$, S. Mangiarotti ${ }^{\text {hi,2,3, }}$, B. Sanou ${ }^{\mathrm{a}}$, Y. Tracole, F.

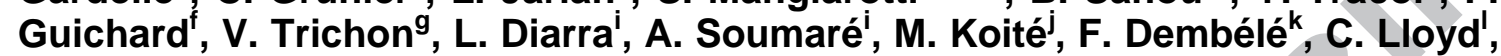
N.P. $\operatorname{Hanan}^{\mathrm{m}}$, C. Damesin ${ }^{\mathrm{n}}$, C. Delon ${ }^{\circ}$, D. Serça ${ }^{\circ}$, C. Galy-Lacaux ${ }^{\circ}$, J. Seghieri ${ }^{\mathrm{p}}$,

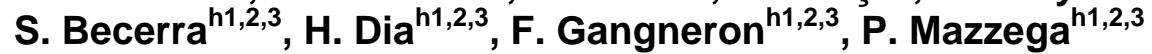

${ }^{a}$ Centre d'Etudes Spatiales de la Biosphère, UMR 5126 (CNRS/CNES/IRD/UPS), 18 avenue Edouard Belin, 31401 Toulouse Cedex 4, France

${ }^{\mathrm{b}}$ Laboratoire de Tranferts en Hydrologie et Environnement,UMR 5564 (CNRS/UJF/IRD/INPG) BP 53, 38041 Grenoble Cedex 9, France

${ }^{c}$ Centre IRD, Quartier Hippodrome, BP 2528, Bamako, Mali

d Laboratoire des Géomatériaux, Université Marne-la-Vallée, France

e Centro de Estudios Avanzados en Zonas Aridas, Casilla 599, colina El Pino s/n La Serena, Chile

${ }^{f}$ CNRM-GAME (CNRS / Meteo-France), Toulouse, France

${ }^{9}$ Laboratoire d'Ecologie Fonctionnelle, ECOLAB, UMR 5245 (CNRS/UPS/INPT), Université Paul Sabatier, 118 Route de Narbonne, 31062 Toulouse cedex 9, France

${ }^{\mathrm{h}}$ Laboratoire des Mécanismes et Transferts en Géologie, UMR 5563 (CNRS/IRD/UPS), 14 avenue Edouard Belin, 31400 Toulouse Cedex 4, France

${ }^{h 1}$ Université de Toulouse ; UPS (OMP) ; LMTG; 14 Av Edouard Belin,

F-31400 Toulouse, France

${ }^{\text {h2 }}$ CNRS ; LMTG ; F-31400 Toulouse, France

${ }^{h 3}$ IRD ; LMTG ; F-31400 Toulouse, France

'Institut d'Economie Rurale, BP 258 - rue Mohamed V, Bamako, Mali

'Direction Nationale de la Météorologie, Bamako, Mali

${ }^{\mathrm{k}}$ Institut Polytechnique Rural, Katibougou, Mali

' Centre of Ecology and Hydrology, Crowmarsh Gifford, Wallingford, OX10 8BB, UK

${ }^{m}$ Natural Resource Ecology Laboratory, Colorado State University, Fort Collins, CO 80523, USA

${ }^{n}$ Ecologie Systématique et Evolution, UMR 8079 (CNRS/U. Paris Sud), Université Paris-Sud, 91405 Orsay, France

- Laboratoire d'Aérologie, UMR 5560 (CNRS/UPS), 14 avenue Edouard Belin, 31400 Toulouse, France

${ }^{p}$ Hydro Sciences Montpellier (HSM), UMR No 5569 (CNRS/IRD/UM1/UM2) Université Montpellier 2 Case MSE Place Eugène Bataillon 34095 Montpellier, France

Deceased on 2007, February 10

Corresponding author. Tel. : +33 561556669 ; fax : +33561558500

Email address : eric.mougin@cesbio.cnes.fr (E. Mougin) 


\section{Summary}

2 The Gourma site in Mali is one of the 3 instrumented meso-scale sites deployed in West3 Africa as part of the African Monsoon Multidisciplinary Analysis (AMMA) project. Located 4 both in the Sahelian zone sensu stricto, and in the Saharo-Sahelian transition zone, the 5 Gourma meso-scale window is the northernmost site of the AMMA-CATCH observatory 6 reached by the West-African monsoon.

The experimental strategy includes deployment of a variety of instruments, from local to meso-scale, dedicated to monitoring and documentation of the major variables characterizing the climate forcing, and the spatio-temporal variability of surface processes and state variables such as vegetation mass, leaf area index (LAl), soil moisture and surface fluxes. This paper describes the Gourma site, its associated instrumental network and the research activities that have been carried out since 1984. In the AMMA project, emphasis is put on the relations between climate, vegetation and surface fluxes. However, the Gourma site is also important for development and validation of satellite products, mainly due to the existence of large and relatively homogeneous surfaces. The social dimension of the water resource uses and governance is also briefly analyzed, relying on field enquiry and interviews.

The climate of the Gourma region is semi-arid, daytime air temperatures are always high and annual rainfall amounts exhibit strong inter-annual and seasonal variations. Measurements sites organized along a north-south transect reveal sharp gradients in surface albedo, net radiation, vegetation production, and distribution of plant functional types. However, at any point along the gradient, surface energy budget, soil moisture and vegetation growth contrast between two main types of soil surfaces and hydrologic systems. On the one hand, sandy soils with high water infiltration rates and limited run-off support almost continuous herbaceous vegetation with scattered woody plants. On the other hand, water infiltration is poor on shallow soils, and vegetation is sparse and discontinuous, whith more concentrated run-off that ends in pools or low-lands within structured endorheic watersheds.

Land surface in the Gourma is characterized by rapid response to climate variability, strong intra-seasonal, seasonal and interannual variations in vegetation growth, soil moisture and energy balance. Despite the multi-decadal drought, which still persists, ponds and lakes have increased, the grass cover has largely recovered, and there are signs of increased tree cover at least in the low lands.

KEYWORDS Sahel; AMMA; Mali; Gourma; vegetation; rainfall; fluxes; long term monitoring; water resource. 


\section{INTRODUCTION}

From the late 1960's, the Sahelian region has experienced chronic below average annual rainfall although a return to wetter conditions has been observed in the last two decades in parts of West-Africa (Lebel et al., this issue). The long dry period has been punctuated by major droughts that occurred throughout out the Sahel in 1972-73 and in 1983-84 with dramatic consequences on water resources and on vegetation cover that triggered soil erosion and massive losses in livestock and aggravated population poverty. Although it is by no means the first arid episode in historical period and during the Holocene (Brooks, 2006), the situation differs by the density of human population and intensity of natural resource use that could aggravate the effect of aridity. This is particularly true in agro-pastoral areas in the Sahel where the growth of population is high and where changes in land cover and soil degradation due to changes in land use, are problematic. Purely pastoral areas of the Sahel suffer less from man induced effects due to a lower population density, and a relatively small impact of grazing compared to clearing land for crops. The changes in vegetation and hydrology observed in the pastoral areas are thus likely more due to climate variation and its effect on hydrological and ecological processes than to land-use. Yet, observations made in this region since the early $20^{\text {th }}$ century have given rise to theories about anthropogenic induced degradation effects by overgrazing and over-exploitation, finally leading to drought and desertification (Stebbing, 1935; Charney et al., 1975). More recent field and remote sensing observations have questioned theses views and the relative responsibility of climate variation and land use changes on the ecosystem production and climate (Giannini et al., 2008 and references therein).

The response at different temporal scales of vegetation and hydrologic systems to chronic (multi-year) dry conditions and acute (single year) droughts experienced in the Sahel remain questioned. Is the Sahelian ecosystem resilient? Are there trends towards definitive aridification? Related to these question is a continuing controversy on the interpretation given to the inter-annual variations in Rain Use Efficiency indices either calculated from field data, or from satellite data using NDVI statistics and rain estimates (Tucker et al., 1991; Prince ,1991; Olsson et al., 2005; Anyamba and Tucker, 2005; Hein and de Ridder, 2006; Prince et al., 2007; Heumann et al., 2007). In addition, consequences of such changes on the interaction between the surface and the atmosphere still need to be assessed with the support of in situ data, very scarce in the Sahel. Moreover, possible thresholds and discontinuities in the dynamics of the ecosystem response to climate changes are expected to be revealed by sampling along the Sahel eco-climatic gradient to the transition with the hyper-arid Sahara desert to the north.

The African Monsoon Multidisciplinary Analysis (AMMA) - Couplage de l'Atmosphère Tropicale et du Cycle Hydrologique (CATCH) site in the Gourma region, in Mali, samples the northern edge of the West African Monsoon (WAM) domain. The site is thus well situated to witness ecosystem changes and related changes in the WAM system. The Gourma region has indeed recorded extremes in the droughts of 1972-73 and again 1983-84, with severe impact on vegetation, crops, livestock and the population (de Leeuw et al., 1992). First observations of drought impacts on vegetation and soils of the Gourma region were reported over a few sites in 1972 (Boudet, 1972) and the sites revisited a few years later (Boudet 1977). The impact of the 1983-84 droughts on rangeland resources was measured on a set of 25 rangeland sites that included some of the sites described by Boudet (Hiernaux, 1984). These sites were selected to sample the North-South bioclimatic gradient, the main vegetation and soil types and a range of grazing intensity, and were regularly monitored until 1995 and more irregularly studied till 2001. The monitoring of these study sites was intensified from 2002 onwards under the AMMA project (Redelsperger et al., 2006) with additional instrumentation at selected sites. The current activities focus on the relationships between climate variability, at different temporal scales, and the main surface processes related to vegetation, hydrology and fluxes. In particular, these studies address a critical 
need for improved documentation and understanding of the long term trends in vegetation in response to climate change. Studies conducted over the Gourma site also complement those performed at the second AMMA-CATCH Sahelian site located in the agro-pastoral region in southern Sahel (Cappelaere et al., this issue).

The present paper aims to describe the research activities carried out at the AMMA-CATCH site in Mali. Firstly, the general characteristics of climate, soil, surface hydrology, vegetation, population and livelihoods in the Gourma site are presented. Secondly, the observation strategy and the associated networks of instrument and monitoring sites are described. Third, main results are summarised with special emphasis on the specific hydrological, physical and ecological processes that prevail at the northern edge of the WAM. The strong seasonal and inter-annual dynamics of the ecosystem are highlighted and long term trends are outlined. Initial findings on the social dimension of water resource are summarized, focusing local social vulnerability to water-related risks, water management practices and the environmental public policy that reflect the effectiveness of the climate change agenda in Mali.

\section{THE GOURMA SITE}

\section{Location}

The northernmost AMMA-CATCH site is located in the Gourma region which stretches from the loop of the Niger River southward down to the border region with Burkina-Faso. The meso-scale site also extends in the Haoussa region, to the north of the Niger River (Fig.1). The study considers staggered scales in three embedded windows. From meso scale to local scale, these windows are:

The Gourma meso-scale site (Fig. 1), a $1 \times 3$ degree area $\left(40000 \mathrm{~km}^{2}\right)$ in the centre of the Gourma region; it extends over the Sahelian bioclimatic gradient from Southern Sahel to the Sahel-Sahara transition. Thirty seven local monitoring sites, each $1 \times 1 \mathrm{~km}$ in size, are distributed along the bioclimatic gradient in three groups: Northern, Central and Southern Sahel. The main soil types are sampled within each group and a range of grazing pressure status (from light to intensively grazed) is sampled among the sandy soil sites.

The Hombori super-site (Fig. 2), a $50 \times 50 \mathrm{~km}$ area $\left(2500 \mathrm{~km}^{2}\right)$ which extends over the central Sahelian bioclimate, at mid latitude within the meso-scale site (15.58 $15.13^{\circ} \mathrm{N} ; 1.75^{\circ}-1.33^{\circ} \mathrm{W}$ ); the super-site includes 9 of the 37 monitoring sites on an array of soil types that is representative of soils in the whole meso-scale site;

Three local sites $\left(1 \mathrm{~km}^{2}\right)$, namely Agoufou $\left(15.3^{\circ} \mathrm{N}, 1.5^{\circ} \mathrm{W}\right)$, (Fig. 3), Eguerit $\left(15.50^{\circ} \mathrm{N}, 1.40^{\circ} \mathrm{W}\right)$ and Kelma $\left(15.2^{\circ} \mathrm{N}, 1.6^{\circ} \mathrm{W}\right)$, representative of the three main substrates within the super site, are more instrumented and more frequently monitored than the other sites.

\section{Climate}

Located towards the northern limit of the area reached by the West African Monsoon, the region experiences a single rainy season with most precipitation falling between late June and mid September. Over the 1950-2007 period, mean annual rainfall was $372 \mathrm{~mm}$ at the Hombori meteorological station $\left(15.3^{\circ} \mathrm{N}, 1.7^{\circ} \mathrm{W}\right)$. The rainy season is followed by a long dry season of $\sim 8$ months in the South increasing to $\sim 10$ months in the North. As elsewhere in the Sahel, the Gourma site experienced a long drought which began in the late 1960s until the end of the 1980's. More average rainfall conditions have been observed since the 1990s (Fig. 4a). Mean air temperature recorded at Hombori is $30.2^{\circ} \mathrm{C}$. The highest monthly value is observed in May $\left(42^{\circ} \mathrm{C}\right)$ whereas the lowest one occurs in January $\left(17.1^{\circ} \mathrm{C}\right)$. 


\section{Geology, topography and soils}

The underlying geology of the Gourma region includes Precambrian sandstones and schists eroded into a peneplain surfaces with occasional plateaus of hard sandstones that have resisted erosion. The Gourma peneplain is at between 250 and $330 \mathrm{~m}$ altitude with highest isolated sandstone buttes reaching 900 to $1100 \mathrm{~m}$. The eroded and exposed peneplain surfaces are locally capped by iron pan formed during the humid period of the Quaternary, but larger areas of the region are covered by deep and stabilized sand dunes deposited during arid periods. Besides these two major landforms, and also inherited from the humid periods of the quaternary remnants of alluvial systems and lacustrine depressions, also formed during humid periods of the Quaternary, can be observed.

Using visual interpretation of a colour composite of Landsat Thematic Mapper (TM) data field observations over the Gourma site, and by supervised classification of SPOT-4 images, nine types of soil substrate are identified including: rock outcrops (schist or sandstones), soils covered by gravels or iron pan, sand dune (bare or fixed), sandy plain, sand sheet, loamy sands, loamy flats, clay plains and flooded depressions. At meso-scale, most land units are mosaics of up to four soil types. However, based on water infiltration and fertility properties, soils types can be gathered into three main categories: sandy soils extending over $58 \%$ of the area, shallow soils on rock and hard pan outcrops extending on $23.3 \%$ and fine textured soils in low lands on $18.7 \%$. In the meso-scale map, the land units (Fig. 1b) have been attributed the dominant (area $>66 \%$ ) category and left to mosaic otherwise. The three main soil categories extend on similar proportion of the land within the Hombori supersite, with 53.9, 29.6 and $16.4 \%$ for sandy, shallow and fine textured soils respectively. As at meso-scale, predominantly sandy or shallow soils distribute in large alternant swaths of contrasted land cover (Table 1), also contrasting with the land cover of the lowland fine textured soils that form a web of narrow bands often slotted in between sandy and shallow soils (Fig. 5). Soil texture for the 3 local sites (Agoufou, Kelma and Eguerit) is indicated in Table 2.

\section{Surface hydrology}

Although the Niger River across northern sector of the Gourma mesoscale site from west to east at $17^{\circ}$ latitude N (Figure 1a), the Gourma is globally endorheic contributes little water to, nor receives water from, the Niger River. Two hydrologic systems characterize the Gourma region. On sandy soils (58\% of the total surface), hydrologic systems are endorheic operating at short distance from dune slopes to inter-dune depressions within small adjacent catchments. On the shallow soils and low land fine textured soils $(42 \%)$, endorheic systems operate over much larger distances with concentrated run-off feeding a structured web of rills ending in one or several interconnected pools. Among them most are temporary ponds but there are a few permanent lakes such as Agoufou and Gossi, this later being the largest within the Gourma site. Away from the Niger River, these ponds or lakes and the local shallow water tables supplied by some of them are the major water resources for the Gourma population and their livestock.

\section{Land cover, vegetation and land use}

As elsewhere in the Sahel, the vegetation of the Gourma comprises a herbaceous layer almost exclusively composed of annual plants, among which grasses dominate, and scattered bushes, shrubs and low trees. The density and canopy cover of woody plants are low on average, i.e. a few hundreds per hectare and a few percent respectively. However, woody plants distribution is highly variable, with higher densities along drainage lines, around pools, in the inter-dune depressions and also on shallow soils. On shallow soils, with the 
narrow linear thickets dominated by shrubs and trees set perpendicular to the slope, known as 'tiger bush' (Hiernaux and Gerard, 1999), can form.

Except for the rice fields of the flooded alluvial plains along the narrow Niger River valley, cropped land only extends in the southern half of the Gourma site over a few percent of the land. The main rain-fed crop is millet grown on sandy and loamy sand soils, with limited areas of sorghum, rice and okra fields in low land clay soils. All areas, including cropped fields after harvest, are used for livestock grazing under communal access. Daily grazing orbits and seasonal moves are used to optimize livestock access to changing water and fodder resources. This results in a range of grazing pressure status, from intensive yearround grazing close to water points and homesteads, to light wet season grazing in area remote from water points. These pastoral land use patterns translate to a web of livestock paths radiating from the water points, and spots with high soil organic matter and nutrient contents localised in livestock resting areas close to water points and camps.

\section{Population and livelihoods}

Analysis of scarce population census data in the Gourma remains to be done to get a clear picture of the actual demographic situation and trends. Yet, after the decrease of the rural population observed in the years following the droughts (RIM, 1987; (Ag Mahmoud, 1992; Hiernaux, 1996), the spectacular development of some of the small towns such as Gossi and the settlement of some of the pastoralists leading to the conversion of temporary camps into permanent villages are indicators of profound changes in society and livelihoods. The food crisis of the droughts in the mid 1970's and early 1980's, and later, the civilian insecurity that prevailed in the 90's, all contributed to increase out migration and settlement in towns. However, the development of modern means of communications with the tar of the main road across the Gourma achieved in 1985, the Gao bridge over the Niger River in 2007, and the recent expansion of the cell phone network also helped. Unfortunately, the lack of reliable statistics on agricultural activities limits the trend interpretation. The total area cropped nowadays in the southern half of the Gourma does not differ markedly from what it was in the 1950's (Gallais, 1975), yet large reduction in area cropped followed the droughts and cropping expansion has been observed since the mid 1990's. The trends in pastoral activity are even more difficult to assess because of the large seasonal mobility of livestock, and the flexibility to adapt these moves to resources opportunities. Livestock population suffered from the droughts (Bourn and Wint, 1985) but seems to have recovered (RIM, 1987), although population moves and changes in management hamper interpretation. The severe droughts of the 1970's and 1980's have focused the interest of the international community on the living conditions and vulnerability of the populations in the Sahel. The setting up of a range of political measures at the regional to local scale to reduce environmental and social costs of such event were organized in most countries prone to droughts or desertification (Dia et al., 2008). After decades of debates and social transformations, it remains difficult to disentangle the environmental and social factors that condition the vulnerability of exposed populations. This particularly applies to access to drinking water that remains a major constraint for livelihood and economic development in the Gourma region, where population has to mostly rely on surface water. Indeed, unlike some other regions of the Sahel (e.g. the Ferlo of northern Senegal), there is no continuous aquifer in the Gourma that could support development of a network of deep wells. As a result the sedentary population in the Gourma concentrates around the relatively few locations with reliable water, while large areas remain poorly and seasonally populated (Ag Mahmoud, 1992).

\section{INSTRUMENT AND MONITORING NETWORK}

\section{Overall strategy}

The overall observation strategy is based on the deployment of a variety of instrument networks, from local- to meso-scales, dedicated to the monitoring and documentation of the 
1 major variables characterizing the climate forcing and the spatio-temporal variability of

2 geophysical and land surface variables. Located on the 3 dominant soil types that can be

3 encountered in the region, the three local sites are extensively instrumented (Table 3). Long

4 term measurements corresponding to the AMMA Long Observing Period (LOP) monitor

5 meteorological variables, vegetation and surface hydrology including soil moisture and water

6 surfaces. Emphasis is also put on the estimation of surface fluxes at local scales and their

7 up-scaling to the super-site scale and finally to meso-scale. Up-scaling of surface fluxes is

8 performed either through weighting by the relative area covered by each landform type

9 (Timouk et al., this issue) or using land surface models and remote sensing data following an assimilation strategy (Jarlan et al., 2008).

Understanding, modelling and predicting plant vegetative phenology (the seasonal cycle of $\mathrm{LAl}$ and biomass and their inter-annual variation) is key to correc prediction of soil moisture, herbaceous production and flux variability. Thus, intensive process field studies that complement the long term monitoring focus on the characterization of the numerous ecological and ecophysiological processes responsible for the phenological cycle of vegetation: carbon assimilation, water uptake and release, vegetation growth and decay, coupled $\mathrm{C} / \mathrm{H} 2 \mathrm{O} / \mathrm{N}$ cycles, etc. Moreover, since soil moisture controls soil evaporation, plant transpiration and thus energy fluxes, soil moisture is monitored at different spatial scales by means of local automatic and satellite measurements. Finally, the overall set up provides data sets, forcing variables and functional understanding of land surface to validate largescale models. In addition, NOx biogenic emissions and dry deposition are measured and related to meteorological variables and surface characteristics such as soil moisture and land use cover. These relations will provide better parameterizations of biogenic emissions and surface characteristics in a Sahelian environment at both local and meso scale (Delon et al., 2007).

\section{Meteorological observations}

The instrument network deployed within the meso-scale site is shown in Fig. 1a. Three Automatic Weather Stations (AWS) were installed along the climatic gradient at Agoufou $\left(15.3^{\circ} \mathrm{N}\right)$, Bamba $\left(17.1^{\circ} \mathrm{N}\right)$ and Kobou $\left(14.7^{\circ} \mathrm{N}\right)$, in 2002, 2004 and 2008, respectively. These stations measure (at a 15 minute intervals) the standard meteorological variables and useful complementary variables such as the 4 components of the net radiation (Table 4). These observations are complemented by those collected by the AERONET sun photometer installed at the Agoufou site, providing information about atmospheric aerosol optical properties and water vapour content (http://loaphotons.univ-lille1.fr/photons/).

Being the most important variable, rainfall is intensively monitored by a network of automatic and manual raingauges that have been progressively installed since 2004. In 2008, this network consists of 32 automatic raingauges distributed within the Gourma meso-scale window, with a enhanced density over the Hombori super-site. These automatic raingauges are complemented by 15 manual raingauges among which 8 belong to Malian rainfall services (Fig. 1a and Fig. 2). In addition, chemical composition of rainfall water and dry and wet depositions as well as gas concentration are provided by the analysis of data collected by a semi-automatic station located at the Agoufou local site. This station belongs to a regional network deployed in West-Africa within the frame of the IDAF Observing System (http://medias.obs-mip.fr/idaf/).

A precise $\mathrm{CO}_{2}$ measurement system installed at the Agoufou site in April 2006 is providing measurements of atmospheric carbon dioxide concentration $\left(\left[\mathrm{CO}_{2}\right]\right)$, with an absolute precision of $0.2 \mathrm{ppm}$ and with continuous and long-term data collection. The Agoufou instrument complements two additional systems in Southern and Central Africa in connection with the GlobalView-CO2 project (www.esrl.noaa.gov/gmd/ccgg/globalview/co2/). As the time-series available at African sites increases much improved inverse quantification of African sources and sinks will be possible (Lokupitiya et al., 2008).

Automatic acquisitions are complemented by measurements of vertical profiles of $\left[\mathrm{CO}_{2}\right]$ in the nocturnal boundary layer (0-200 m altitude) measured with a tethered balloon. Boundary 
1 layer budgets based on measurements allow estimations of sensible, latent and $\mathrm{CO}_{2}$ fluxes at

2 a scale larger than that of the flux stations. The Low Level Jet, which essentially is the

3 monsoon flow, has been portrayed with the frequent tethered balloon profiles (Bain et al., in

4 revision).

\section{Surface hydrology and water cycle observations}

Runoff in the Gourma region depends on soil depth, texture and rainfall patterns. In endorheic catchments on sandy soils, evaluation of run-off, run-on and infiltration processes are performed thanks to data recorded by soil moisture stations that have been installed at the top, middle and bottom locations of dune slopes at the Agoufou site. In addition, a joint monitoring of the seasonal dynamics of the unsaturated zone associated to vegetation dynamics is performed along a 'hydrological' transect that crosses a series of endorheic catchments (Fig. 3). This set-up is designed to address the interactions between water redistribution and herbaceous and woody vegetation patterns, and between vegetation dynamics and production and soil moisture availability.

Over wider areas, documentation of the spatio temporal variability of soil moisture content is performed using local automatic measurements collected by a network of 12 soil moisture stations deployed within the Gourma meso-scale window (Fig. 1). Automatic acquisitions are complemented by field surface measurements performed along transects of $1 \mathrm{~km}$ to $50 \mathrm{~km}$ long with the objective of satellite products validation. A detailed description of the soil moisture network and the associated up-scaling methodology can be found in de Rosnay et al. (this issue).

Water losses through evaporation and plant transpiration is studied through eddy-correlation measurements performed through 4 flux stations, including 2 heat flux and $2 \mathrm{CO}_{2} / \mathrm{H}_{2} \mathrm{O}$ stations, that were installed within the Gourma site since 2005. Among them, 3 are installed within the Hombori super-site on representative dominant surfaces, namely the Agoufou woody savannah on sand dunes (Fig. 6), the Kelma open Acacia forest on clay soil, and on a bare soil patch at the Eguerit rocky erosion surface (Fig. 2). The fourth flux station is positioned on almost bare sands in the northern part of the Gourma window at the Bamba site otherwise characterized by sparse perennial herbs and very scattered trees. These stations are part of the CarboAfrica project (www.carboafrica.net) whose eddy-correlation measurement stations are distributed on the major African ecosystems.

Flux measurements at the Hombori super-site are complemented by sap flow measurements performed on representative tree species: Acacia senegal, Acacia raddiana, Combretum glutinosum and Balanites aegyptiaca at the Agoufou site and Acacia seyal at the Kelma site. These automatic stations give an estimation of the transpiration from trees, providing useful data to interpret the measurements made by the flux stations.

Besides the measurements made on the soil unsatured zone, manual observations of the water level of the Agoufou pond has been performed weekly since 2007. The monitoring of the seasonal and inter-annual variations of its surface extent is based on different sensors including aerial photographs and satellite images at different spatial resolution namely Landsat, SPOT-4, MODIS, CORONA and FORMOSAT (Gardelle et al., 2009).

\section{Vegetation monitoring and ecophysiology}

The monitoring of the vegetation is based on the survey of $371 \mathrm{~km} \times 1 \mathrm{~km}$ sites distributed along the North-South bioclimatic gradient (Fig.1). Measurements are made every month during the rainy season for three plant functional types namely, annual herbs, perennial herbs and trees. At the Hombori super-site over the Agoufou, Kelma and Eguerit local sites, the seasonal variation of Leaf Area Index (LAl), vegetation cover, plant height, herbage above- and below ground masses, and floristic composition are monitored every 10 days during the growing season along a $1 \mathrm{~km}$ long 'vegetation' transect (figure 3). Tree and herb $\mathrm{LAl}$ is estimated using hemispherical images (Mougin et al., in preparation). Phenology of the main tree species is also measured along the climatic gradient using sampling techniques detailed in Hiernaux et al. (1994). At the different sites, woody population dynamics are 
1 regularly monitored (Hiernaux et al., 2009a, this issue). The survey includes the estimation of 2 tree density, tree height, crown cover, wood and foliage masses.

3 In addition, automatic measurements of Photosynthetic Active Radiation (PAR) interception 4 by tree canopies complement LAI measurements and provide useful data for process model 5 development and validation. Incident and transmitted PAR cells installed at the Agoufou 6 savannah site (Fig. 3) and Kelma open forest site provide time variation of the fraction of 7 PAR absorbed by the vegetation layer.

8 In addition to automatic acquisitions, intensive field campaigns are carried out at the three 9 local sites. Field work mainly consists of ecophysiological measurements aiming at charactering the plant and soil response to their environment, particularly to water availability. This includes measurements of stomatal conductance, leaf water potential, and gas exchange (transpiration and photosynthesis). Associated to laboratory chemical analysis of soil and vegetation samples, these measurements provide the necessary input parameters for land surface models and for model parameterization. Since 2004, intensive field measurements have been performed in collaboration with international teams like the Climate and Land Surface Systems Interaction Centre (CLASSIC, http://classic.nerc.ac.uk/IGBP.php) in the United Kingdom and the TROpical Biome In Transition (TROBIT, www.geog.leeds.ac.uk/research /trobit/) project. The list of surface variables monitored at different spatial scales is given in Table 5.

\section{Remote sensing survey}

Since 1984, the study sites of $1 \times 1 \mathrm{~km}$ in size have been selected, whenever possible, within $3 \mathrm{~km} \times 3 \mathrm{~km}$ similar surfaces allowing monitoring to be conducted with medium and coarse resolution satellites such as the Advanced Very High Resolution Radiometer (AVHRR) onboard the National Oceanic and Atmospheric Administration (NOAA) series (Hiernaux and Justice, 1986). The presence of large homogeneous and flat surfaces characterized by a high seasonal and inter-annual variability makes the Gourma site particularly well suited both for methodological development and for multi product validation exercises.

Seasonal, inter-annual and decadal variations of vegetation cover, LAI and herbage production are assessed and mapped through Normalised Difference Vegetation Index (NDVI) values derived from various satellite sensors operating at different spatial resolutions in the optical domain (Hiernaux and Justice, 1986; Lo Seen et al., 1995). Besides, surface soil moisture (SSM) variations have been monitored by both active and passive microwave sensors, including the European Remote Sensing (ERS) Synthetic Aperture Radar (SAR), the ENVISAT-Advanced Synthetic Aperture Radar (ASAR) and the Advanced Microwave Scanning Radiometer (AMSR-E).

Associated to an appropriate field sampling strategy at different spatial scales, the Gourma site has been extensively used for the development of multi-spectral remote sensing inverse methods, particularly with the following sensors: European Remote Sensing (ERS) wind scatterometer (e.g. Frison et al., 1998; Jarlan et al., 2002; Zribi et al., 2009), Special Sensor Microwave/lmager (SSM/I) sensor (Frison et al., 2000), ERS-SAR (Zine et al., 2005), SPOT/VEGETATION (Jarlan et al., 2008; Mangiarotti et al., 2008), ENVISAT- ASAR (Baup et al., 2007). Current activities focus on the evaluation of important surface variables for model initialisation and spatialisation like the MODIS derived albedo and LAI products (Myneni et al., 2002), and the AMSR-E (Gruhier et al. 2008) derived SSM products (Fig. 7). Such an evaluation is crucial before their assimilation in land surface models. More details on the validation exercise over the Gourma site can be found in Samain et al. (2008), de Rosnay et al. (this issue).

Since 2000, the Gourma sites have been integrated in the site network of the Validation of Land European Remote sensing Instruments (VALERI) (Baret et al., 2009; www.avignon.inra.fr/valeri/) and Committee on Earth Observation Satellites (CEOS) / Land Product Validation (Morisette et al., 2006; http://lpvs.gsfc.nasa.gov/) projects. Among the selected validation sites, the Gourma site stands out as the site with the lowest spatial heterogeneity when high- (SPOT) and low- resolution (MODIS) products are compared 
(Garrigues et al., 2008). In addition, the Gourma site network has been retained as ESA calibration/validation site for the forthcoming Soil Microwave and Ocean Salinity (SMOS) mission (http://www.esa.int/esaLP/LPsmos.html).

\section{Human population, natural resource management and societies}

A several-year cycle of observations (interviews, enquiries, etc.) has been initiated in the commune of Hombori, with three main objectives: analysis of the spatio-temporal patterns of the water resources availability; identification and analysis of the social vulnerability to water risks; observation and interpretation of the multi-level social and political management of the resources. The data are organized in a GIS with other layers on the proximity with villages, campsites, roads or tracks, the availability of other resources (wood, pastures, fishes, etc.) and the related extractive or exploiting activities.

\section{Integration in observation networks}

In Mali, the AMMA-CATCH site is associated to the 'Observatoire du Gourma / Réseau National de Surveillance Environnementale (RNSE) coordinated by the University of Bamako/FAST. In addition, the northern sites of the Gourma site, located north on the left side of the Niger River, are part of the ROSELT/OSS (Réseau d'Observatoires de Surveillance Ecologique à Long Terme / Observatoire du Sahara et du Sahel) network (www.roselt-oss.org/pays/mali/). As part of these activities leading national collaborators include Institut d'Economie Rurale (IER-Bamako), Centre de Recherches Régional Agronomique (CRRA-Gao), Direction Nationale de la Météorologie (DNM-Bamako) and the Faculté des Sciences et Techniques (FAST-Bamako).

\section{MAIN FINDINGS}

\section{Spatial patterns along the bioclimatic gradient}

The Gourma mesoscale site is a $3^{\circ}$ north-south by $1^{\circ}$ east-west transect with a series of monitored sites distributed on the dominant soil surfaces along the rainfall gradient. The rationale in establishing study sites along such an extended transect lies in the possibility of long-term monitoring on a climatic and ecological gradient. This is the reason why several transects have been designed in different eco-climatic zones of semi-arid regions like the Northern Australia Tropical Transect (NATT) or the Kalahari transect (Canadell et al., 2002). The following paragraphs summarize the main findings of this 'transect' approach.

\section{Climate}

The whole transect is under the influence of the West African monsoon. The Inter Tropical Discontinuity, which separates the south-westerlies monsoonal winds from the northeasterlies Harmattan wind, crosses the Gourma on its way North, on average in May and in October on its way South (Flamant et al., 2009). Rainfall is concentrated in the core of the monsoon season, which extends from late June to mid September. Rainy season duration and the annual total rainfall decrease with increasing latitude characterized by an average annual rainfall of $450 \mathrm{~mm}$ in the south of the Gourma meso-scale window progressively declining to $150 \mathrm{~mm}$ in the north (Frappart et al., this issue). The rainfall gradient is therefore about $1 \mathrm{~mm} \mathrm{~km}^{-1}$, a value commonly reported for the Sahel climatic gradient (Lebel et al., this issue). The number of rainfall events decreased with latitude, and each rainy day brings, on average, slightly less rainfall than further south. Maximum air temperature and diurnal temperature ranges increase from the south west edge of the Gourma region to the northern one, thus following the aridity gradient.

The Gourma transect samples an extremely sharp gradient of surface albedo and net radiation. Since soils are bright sands and vegetation is sparser at the northern edge of the Gourma site, surface albedo reaches values as high as $40 \%$ throughout the year at Bamba 
$\left(17.1^{\circ} \mathrm{N}, 1.4^{\circ} \mathrm{W}\right)$ whereas albedo values vary from $20 \%$ (wet season) to $35 \%$ (dry season) at Agoufou $\left(15.3^{\circ} \mathrm{N}, 1.5^{\circ} \mathrm{W}\right.$ ) (Samain et al., 2008). Net radiation is inversely correlated with the albedo gradient. During the monsoon season, the daily average net radiation is maximum near $15^{\circ} \mathrm{N}$, and decreases northward to $17^{\circ} \mathrm{N}$ (Fig. 8), typifying the reduced radiation budget of desert and semi-desert areas related to increasing albedo (Timouk et al., this issue). The moist static energy (Guichard et al., this issue), whose latitudinal variations impact the intensity of the monsoon flow, also decreases from Agoufou to Bamba.

\section{Vegetation}

Over most of the Gourma site, annual plants largely dominate the composition of the herbaceous layer as elsewhere in the Sahel. However, perennial herbaceous, especially grasses and sedges, are more common towards each of the two transitions zones. Tussock perennials, such as Andropogon gayanus and Cymbopogon giganteus occur in some of the loamy sand depressions to the south of the Gourma mesosite, while the tussocks of Panicum turgidum, Aristida sieberiana and Cyperus jeminicus, colonise the dunes north of the Niger River.

Although the diversity of the herbaceous species is generally low as elsewhere in the Sahel and species composition quite variable from year to year at a site, there are trends in species composition with long cycle annuals such as Diheteropogon hagerupii, Pennisetum pedicellatum and Schoenefeldia gracilis becoming more frequent in wetter sites to the south of the region. Woody plant species diversity also increases with rainfall: many woody species common in the Sudanian zone are not present north of the $450 \mathrm{~mm}$ isohyet such as Sclerocarya birrea, while others do not grow north of the $300 \mathrm{~mm}$ isohyet such as Combretum glutinosum and Pterocarpus lucens. However, there are also species common in the arid and hyper-arid zones which are not spontaneous in more humid zones such as Salvadora persica, Euphorbia balsamifera, Maerua crassifolia and Acacia ehrenbergiana.

Herbaceous production decreases and its interannual variability increases on sandy and shallow soils as climate becomes drier along the gradient (Fig. 9). However, herbaceous production on clay soils in depressions across the full transect is similar because because vegetation growth in these sites is driven by run-on and flood regime rather than by precipitation per se. Similarly there is a weak trend of decreasing woody plant density, canopy cover and height on sandy soils and shallow soils, as climate gets drier along the gradient, but this relationships is not seen on clay soils (Hiernaux et al., 2009a, this issue).

\section{Two contrasted soil and hydrologic systems}

In addition to the latitudinal arrangement along the climatic gradient, the Sahelian ecosystem of the Gourma site is patterned by the juxtaposition of contrasted soils and hydrologic systems across most of the rainfall gradient except in the northern transition zone to the Sahara (north of the Niger River) which is dominated by sand dunes (Fig. 1)

\section{Soils and hydrologic systems}

The hydrologic behaviour (run-on/run-off balance) of each unit in the supersite soil map, has been rated during a field survey, based on the expected water infiltration of the soil and the topography. The rate used is the value of the coefficient $(\alpha)$ of the empirical relationship between total infiltration or balance index $(\mathrm{I})$ resulting from a precipitation $(\mathrm{P})$ and a standard precipitation of $10 \mathrm{~mm}$ (Hiernaux, 1984): I = P + $\alpha(2 P-10) / 10$

Among the values taken the coefficient $\alpha$, nine typical values between -4 (high losses by runoff) and 15 (extremely high gains due to large external inputs) have been retained to characterise the hydrologic behaviour each soil unit. As expected from an overall endorheic system, the area weighed mean of the run-on/run-off balance rate calculated over the whole super-site is almost null (-0.1). The slightly negative value of the weighed mean results the 
1 slight imbalance between dominant run-off on rocky soils (-3.5) and loamy soils $(-1.5)$, 2 balanced sandy soils (0.0), and dominant run-on on clay (+4.5) and sandy-loam soils (+2.2).

3 Anomalies of mean NDVI anomalies calculated over the wet season on a series of 2000-

42006 MODIS images confirm the empirical rating, highlights the partition of the Gourma into 5 two contrasted hydrologic systems. Sandy soil catchments consistently present small 6 anomalies and relatively high mean NDVI values, while watershed on otherwise textured 7 soils have large anomalies and relatively low mean NDVI values.

Soils and soil moisture

In addition to rainfall variability, run-on / run-off balance driven by soil types and geomorphology play an important role on the spatial patterns and dynamics of soil moisture (de Rosnay et al., Timouk et al., this issue). Clay soils located in depressions with surface run-on are temporarily flooded during the rainy season. Due also to their high clay content, these surfaces exhibit the highest soil moisture (SM) values maintained at saturation during flooding events. In contrast, rocky soils characterized by high run-off fraction show low SM values. Lastly, the endorheic sandy systems, characterized by limited run-on / run-off processes and by a high infiltration rate, show a well pronounced SM dynamics characterized by fast variations of the surface soil moisture (Fig. 10a). In sandy soils, surface flows and surface ponding rarely occurs and then only in limited areas for short time periods (i.e. a few hours).

\section{Vegetation}

Large differences in annual production of the herbaceous vegetation are observed between sites belonging to the two hydrologic systems. Herbaceous yields are systematically low on the shallow soil sites for which a large fraction of the rainfall is lost by run-off whereas lowland fine textured soils present extreme values depending on success or failure of plant seedlings to withstand flood. At inter-annual scales, production on sandy soils varies less dramatically, with mean values between that of rocky soils and depressions. The spatial heterogeneity of the herbaceous layer can been assessed as the coefficient of variation of above ground biomass in 100 random samples $\left(1 \mathrm{~m}^{2}\right)$ taken at peak biomass each year (towards the end of the wet season (Hiernaux et al., 2009b, this issue). The coefficient of variation of the herbaceous layer ranges between 50 and $75 \%$ in low land clay soils, 50 and $100 \%$ in sandy soils, and 75 and $150 \%$ in shallow soils. Part of the high values reached by herbaceous spatial heterogeneity is explained by the relative extent of bare soil patches that on average cover only $6 \%$ of the area in sandy soils sites, but $72.3 \%$ on lowland clay and $83.5 \%$ on shallow soils.

Woody plant populations also differ markedly between soils types, by the density of the woody plants, their size and canopy cover, but also with regard to spatial distribution mode and species composition. Over the super-site, canopy cover of woody plants reaches $9.5 \%$ shared between bushes $(5.8 \%)$, shrubs and low trees $(3.7 \%)$. Woody plant cover are unequally distributed in the landscape with $40.3 \%$ canopy cover in low land clayed soils, $12.2 \%$ in the loamy-clay to loamy-sand soils of flats and valleys, $5.7 \%$ in sandy soils and $2.9 \%$ in shallow soils. The spatial distribution of the woody plant varies from near random in some Acacia seyal forest in lowlands or Euphorbia balsamifera open stands on loamy sands, but are more often aggregated in relation with the pattern of soils, micro-topography and runoff/run-on balances.

Soils and their associated hydrologic properties also largely determine the woody plant species composition. Three dominant species contribute equally, for $13 \%$ each, to the woody plant cover in the supersite: Acacia raddiana, predominantly but not exclusively on sandy soils, the ubiquitous Balanites aegyptiaca and Acacia seyal which dominates in the low land forest on flooded clay soils. Acacia ehrenbergiana and Boscia senegalensis, common on shallow and sandy-loam soils contribute each to $9 \%$. Another three species account for 5-6 $\%$ each: Combretum glutinosum on sandy soils, Anogeissus leiocarpus on flooded loamy 
soils and Acacia nilotica on flooded clay soils. Together these 8 species account for $73 \%$ of the cover, the 13 other species all account for less than $5 \%$ of the woody cover.

\title{
A brief and hectic rain season
}

\begin{abstract}
Seasonal cycle
Surface energy budget, soil moisture and vegetation growth are markedly shaped by the alternation of a long dry season and a short rain season, as detailed in Guichard et al., de Rosnay et al., Timouk et al. (2009, this issue) and Hiernaux et al. (2009b, this issue). Being at the northern edge of the WAM domain, the average rain season in the Gourma only lasts 120 days on average in the south and 60 days on average in the north with 30 to 12 rainy days from south to north across the Gourma site (Frappart et al., this issue). The rainfall is made of several major rain events with important intermittency. Not surprisingly, this is reflected in many aspects of eco-hydrology in the Gourma. The rapid germination and growth of the annual grasses and dicotyledons is a prime example of such a sharp cycle. During the period of seedling establishment, characterized by active root growth, LAI remains at low values, below 0.1 at the Agoufou local site in 2007 (Fig.10). Then, if soil moisture permits, as after DoY 210 of 2007 at Agoufou, following heavy rains,growth is rapid till the end of August. At Agoufou, maximum LAl was reached on DoY 235 (August 22 2007) followed by the beginning of senescence triggered by the lack of water in the rooting zone. C4 annual grasses display very high photosynthesis rates (Damesin et al. unpublished data), which sustains the rapid growth whenever soil moisture is available between seedling establishment and flowering. In September 2007, the overall decrease of the green vegetation at Agoufou was buffered by late rainfall events occurring between DoY 238 and 258. However, the bulk of the herbaceous production is achieved within a few days or weeks of active production so that the level of herbaceous yield is largely determined by the duration and soil moisture condition of that period. In turn, the rapid plant growth greatly impacts the land surface properties like the energy balance and water fluxes. The synchronized response of surface albedo and LAl can be seen in Fig.7a and Fig. 10b, with a time lag between these two variables and soil moisture (Fig. 10).
\end{abstract}

\section{Intra-seasonal variations}

In addition to the shortness of the rain season, plants are confronted with a high level of uncertainty in the timing and consistency of rainfall within the growing season. It is frequent that the first germinations dry out due to a lack of rain, while the subsequent cohorts of plants grow normally and produce seeds. Sequences of 5 to 10 days without precipitation are frequent even during the core of the rainy season and the frequency and duration of these intra-seasonal droughts increase with latitude (Frappart et al., this issue). These dry spells considerably modify the surface energy budget and evapotranspiration, as shown on Fig. 8 and Fig. 10c for the Agoufou grassland in 2007. During a dry spell starting after the rainfall of DoY 240 , the latent heat flux decreases rapidly during a 7 days dry period, whereas the surface energy is increasingly dissipated as sensible heat flux. During the dry spell, soil moisture is depleted and plant growth is interrupted (Fig. 10a, b). The system switches back to moist conditions after the rain of DoY 249 , immediately for latent and sensible heat fluxes (Fig. 10c), after two days for the $\mathrm{CO}_{2}$ flux (Fig. 10d). Plant growth also rapidly resumes, which shows how quickly Sahelian grasslands can recover after a short dry spells during the growing season.

\section{Large inter-annual variations}

\section{Climate}


The varying number and intensity of rain events observed during a rainy season at Hombori generate an important inter-annual variability in soil and vegetation growth. The AMMA Enhanced Observing Period (EOP), sampled three different years: 2005 (total 408mm) provided a long and regular rain season close to the climate average. 2006 (total $377 \mathrm{~mm}$ ) was characterized by a very late but intense rain season, whereas 2007 (total $291 \mathrm{~mm}$ ) was also very late but well below the long-term average (Fig. 4b). The rainfall recorded from 2005 to 2007 are largely above the $167 \mathrm{~mm}$ recorded in 2004 , which in the Gourma, was a drought almost as extreme as the 'historical droughts of 1973 and 1984.

\section{Inter-annual variability of vegetation}

Most of the Inter-annual variation in annual herbaceous production result from inter-annual variation in the soil moisture regime driven by rainfall volume and distribution as illustrated by the variations of herbaceous green mass at Agoufou during the 2005, 2006 and 2007 wet season (Fig 11). However, it may occur locally, that the seed stock limits growth, either because rainfall were insufficient in previous years for plants to seed because intense herbivory reduced seed production, or else because high seed consumption by rodents or birds has depleted the seed stock. More generally, since the herbaceous cover originates every year from the germination of seeds produced mostly during the previous growing season, and because annual plants respond strongly and quickly to soil water availability, frequent and abrupt changes in species composition have been observed. However, these shifts are not linked to the inter-annual variations in herbaceous production (Hiernaux et al., $2009 b$, this issue).

For perennial components of the vegetation, there are inter-annual variations in the production of established individuals and variation in population recruitment and mortality rates. Compared to annual plants, the production variations are buffered by the wider growing season and the benefit from soil moisture stocked over consecutive years. Yet, interannual discrepancies measured in maximum leaf mass per standard branchlet on an array of woody species reached proportions of 4 to 1 in extreme cases (Hiernaux et al., 1994). Even more fluctuant between years are the mortality and cohort recruitment events, contributing to the decoupling of woody population dynamics from annual climates.

\section{Inter-annual variability in surface properties and energy fluxes}

The difference in rainfall between 2005 and 2006, illustrated in Janicot et al. (2008), produced a dry anomaly throughout the Sahel in early 2006, indicated by a significant AMSR-E derived soil moisture anomaly, leading to a negative anomaly of early season NDVI. The core monsoon season however is characterized by a reversal of the anomalies, which turn positive, showing that plants were able to recover, and even produce more greenness, in 2006 compared to 2005. This scheme applies to the whole central and northern Sahel and holds also true for the Gourma (Fig.11). As a result, surface albedo and net radiation obey the same logic, with net radiation and albedo reaching similar values in 2006 and 2005 (Samain et al., 2008). Data from 2007, however demonstrate that plant recovery is significantly impaired if the late season rainfall are insufficient to compensate a late start of the monsoon season. In terms of energy balance, 2004 was remarkable in the sense that the seasonal cycle was almost completely suppressed by the drought, because of a very poor vegetation growth for the Agoufou site (Samain et al. 2008).

\section{Long term trends}

\section{Climate}

Compared to the wet period of the 50s, the annual rainfall amount in the 1970-2007 dry period shows a $20 \%$ reduction translating to a southward shift of the annual isohyets (Frappart et al., this issue). The length of the rainy season has decreased during the 1950- 
12007 period due to both a delay of the starting date and an earlier ending. Results show that 2 the decrease of the number of rainy days in the Gourma site in the last decade may be 3 associated to an intensification of the daily rainfall.

4 Since 1950, the observed mean annual air temperature increase is about $0.7^{\circ} \mathrm{C}$. This 5 increasing trend mainly affects the minimum temperatures, which have increased $1.3^{\circ} \mathrm{C}$, This trend is consistent with the observations made over the West African Sahel showing that the increase is higher at the driest edge of the Sahel (Zhou et al., 2007).

\section{Surface waters}

In apparent contradiction with the negative precipitation trend, the analysis of the long term remote sensing data showed evidences of a general increase in the surface of the Gourma ponds over the last 50 years (Gardelle et al., 2009). Moreover, after the major droughts of the 1970s and 1980s some temporary ponds became permanent. A particularly striking example is the increase of the Agoufou pond area as quantified by the classification of remote sensing images; its size at the end of the rainy season was less than 10 ha in the sixties, increased to about 60 ha in 1996 and it is nowadays between 440 and 560 ha (Fig. 12). Corresponding calculated normalized anomalies of the surface extent of the Agoufou pond show very negative values in 1954 and 1965 i.e. during the wet period whereas positive values are found since 1990, in a context of drier years (Fig. 13). However, note that the very dry 2004 year exhibits the only negative anomaly within the last decade.

These observations are in agreement with the increase of surface runoff reported for some other Sahelian region (e.g. Favreau et al., 2009; Cappelaere et al.; this issue; Descroix et al., this issue) yet its causes are not yet fully understood. The intensification of agricultural activities and the associated increase of crusted soils suggested as a possible explanation for the South West Niger region does not hold for the Gourma site, where agriculture has a minor impact and where, more likely, causes are to be sought in the decrease of vegetation and in the modification of soil surface characteristics following the major droughts of the 1970s and 1980s.

\section{Vegetation}

Long term trends like the shift to more arid tolerant species after the 1984 drought and the slow return to typical Sahelian flora, can only be identified through systematic and regular observations performed over long period of time as they are masked by high inter-annual variability (Hiernaux et al., 2009b, this issue). This applies particularly to tree population dynamics which operate at a longer time scale than that of the herbaceous cover (Hiernaux et al., 2009a, this issue).

Dramatic variations of the woody cover occurred during the study period following the 198384 drought, which affected all the woody populations (Fig. 14 and Fig. 15). Following the drought-induced mortality and in spite of below average rainfall conditions, woody populations have recovered in most sites as illustrated by site \#17 on sandy soils and site \#21 on clay soils, apart from specific situations possibly linked to land use history (fire, clearing, camp settlement) like on the site \#31. Tree density and canopy cover have strongly increased in temporarily flooded open forests on clayed plains (e.g. site \#21) which benefit from increasing run-off water originating from adjacent shallow soils. Similar observations are made along the latitudinal gradient and there is no evidence for a higher sensitivity to drought at the driest end of the rainfall gradient.

Fig. 16a-16b display the normalized rainfall anomaly index (Lebel and Ali, this issue) for the Hombori meteorological station over the 1984-2007 study period, and a similar normalized index calculated from measurements of herbaceous production performed on 3 sandy sites at the Hombori super-site. Only observations collected on endorheic sandy soils are reported here as they are more directly related to rainfall variations. The range of variability is of the same order for the two data sets, but with slightly higher variability in annual rainfall than in herbage production. In contrast to observations made over the Niger site (Hiernaux et al., 
1 2009c, Cappelaere et al., 2009, this issue), there is no evidence for a long term decreasing 2 trend in herbage production which remains strongly related to the rainfall amount and above 3 all to the temporal distribution of rainfall events (see also, Hiernaux et al., 2009b, this issue). 4 These results point out the strong resilience of the herbaceous cover on sandy soils in the 5 Sahel.

\section{The human dimension}

\section{Social dimensions of the water resource}

The most striking character of the water resource in the commune of Hombori is the diversity of local situations: practically every village or pastoral camp has a particular relationship with the resource. It results from the combination of different factors: a) the types of water availability (lakes, pools, shallow wells); b) the types of access modes including various extraction devices, sources of energy and transportation modes; c) the rules framing the legitimacy, precedence and other determinants of access to the resource; d) the economical conditions for accessing and extracting the resource; e) the organization required to maintain the resource and access. These local observations might be representative of a many municipalities in the Gourma or even in the Sahel.

\section{Social vulnerability to the water resource and management}

Monsoon variability is recognized as a key determinant of water security, by the social groups that organize their life in a way that provides the maximum advantage of these environmental features. However, the capacity for these populations to overcome crises is limited by several factors. It has been observed that, in response to the severe droughts, several of the surveyed households diversified their portfolio of activities and resource uses (Thébaud, 2002). This was possible due to the availability of a diversity of resources on a restrained territory and because their accessibility and exploitability were susceptible of social rearrangements. From enquiries among households in Hombori, a few structural patterns conditioning the social vulnerability to water-related risks can be identified: a) the scarcity of permanent potable water points; b) the lack of maintenance of some water devices available for collective uses; c) the concurrent uses in the same places that often results in the spoiling of the freshwater; e) the absence of treatment plants. Yet, not all social groups are equality exposed to risks, and exposure depends on the activity. The most often evoked risk concerns human health. The risk of water shortage is related to the intensity of the rainy season and on the threats put on the agriculture production and food security. The water use requires an every day hard labour usually done by women. Recurring water scarcity directly increases this burden and intensify the vulnerability of the corresponding groups.

Water resource management practices and governance

Water management, effective at the local scale, is embedded in a national policy frame which may explicitly concern the resources like in the National Plan for Environment (1998), the Pastoral Charter (2001) and the Orientation Law for Agriculture (2006). It can also constitute a deeper legal trend that impacts resource management and governance like the adoption of decentralization measures (Kassibo, 1997; Dia, 2006) and the consequent transfer of environmental liability to territorial authorities. Three kinds of legal instruments are operated: a) orientation instruments that define objectives (food security, institutional tools to protect the environment, etc;) and open the possibility for local actors to assume environmental responsibilities; b) binding regulations that introduce new obligations and permissions regarding the access and uses of resources; c) incentives that allow for negotiated local arrangements between the stakeholders (Dicko and Djiré, 2007). Yet the local practices are far from these idealized frames, most often reflecting the concurrent uses of resources and the development of strategies by the local actors. Surface water such as 
1 ponds for example, is the main water resource that has always been used as drinking water 2 for human and livestock, for washing, for several craft activities, and it is increasingly used 3 for gardens irrigation and fish breeding. Opposite to some well or borehole water, pond 4 water remains a free public good in Hombori. However, the access to pond water may be 5 regulated, at least seasonally when becoming scarce, either by infrastructures like crop field 6 and fences that impede or channel the access of livestock or else through priority 7 arrangements between use and users. In some particular case, the use of water is paid 8 either in kind (fetch water to irrigate) or money (right to breed fish in ponds). The beneficiary 9 of this fishing tax is not clearly stated by law and generates conflict between village 10 customary and district authorities. 


\section{CONCLUSION}

Taking advantage of existing data sets on climate and vegetation, the AMMA-CATCH research activities at the Gourma site in Mali are widely multi-disciplinary and rely on the deployment of a large network of instruments across the climatic gradient. The up-scaling of local-scale results is achieved by remote sensing and modelling tools. During the AMMA Enhanced Observing Period (2005-2007), numerous investigations of eco-physiology and land surface processes have been carried out. The combined use of the Long Term Ecological survey (1984-present) and the results of the recent process studies should allow us to reanalyse historical survey data and develop realistic scenarios on the role of land surface in the transition from the wet period $(1950$ - 1970) to the dry period (1970 to present). Such realistic scenarios are crucial for a correct interpretation of surface/atmosphere feedback loops. Furthermore, the combination of long term surface dynamics monitoring with detailed process studies establishes a much awaited basis for future climate/land surface simulations in West-Africa.

The variation in rainfall across the Sahelian climatic gradient shows a $1 \mathrm{~mm} \mathrm{~km}^{-1}$ in rainfall with increasing latitude. From South to North there is also a sharp gradient of surface albedo and net radiation, a decrease in mean vegetation production yet increasing variability from year to year, at least on sandy and shallow soils. The distribution of vegetation functional types also follows the latitudinal arrangements: with more perennial herbaceous at both extremities of the gradient, the functional diversity of annual herbaceous decreasing with latitude as well as the woody plant density, size, cover and species diversity.

However, at any point along the gradient, surface energy budget, soil moisture and vegetation growth contrast between two main types of soil surfaces and hydrologic systems. On the one hand, sandy soils with high water infiltration rates and limited run-off within small endorheic catchments, support almost continuous herbaceous layer with scattered woody plants. On the other hand, water infiltration is poor on shallow soils and lowland fine textured soils, generating large concentrated run-off that ends in pools within structured endorheic watersheds. The vegetation cover of these watersheds is extremely patchy, with large areas remaining bare of herbaceous all year round, and large areas with very scattered shrubs contrasting with small areas of dense linear thickets and low land forest. Because of the distinct soil surface, soil moisture regime and vegetation growth, the two main hydrologic systems also contrast in albedo, energy balance, water and $\mathrm{CO}_{2}$ fluxes. The short duration of the rainy season and the determinant role of a few major rain events with important intermittency reinforce the functioning contrast between the two hydrologic systems.

The long term dynamics of the ecosystem seems to also diverge between the two hydrologic systems that share the landscape. Indeed, the vegetation of the sandy soils is more sensitive and responds more rapidly to drought than vegetation on rocky soils or in the depressions. But the vegetation demonstrated large resilience, so that even if some components such as the woody plant population remained affected over longer time the ecosystem functioning recovered after a couple of years. On the contrary, deep structural and functional changes triggered by the droughts have persisted if not aggravated in the gravelly watersheds. On the watershed slopes, vegetation cover kept regressing over decades following drought, and its partial recovery adopt new patterns marked by the increased run-off and soil erosion that resulted from the large and durable opening of the herbaceous layer. At the watershed scale increased run-off has fed the swelling of ponds in apparent contradiction with the negative precipitation trend. The impact of the increased run-on on lowland vegetation is more variable depending on the associated change in flood regime, but globally there is a significant increase in woody plant population density and cover in lowlands.

Although much of the research is still active, the Mali site of AMMA-CATCH is already contributing through scientific publications including papers in this special issue of the 
1 Journal of Hydrology to a better knowledge on the physical, hydrological and biological 2 processes at soil surface in relation with the West African Monsoon. Some elements of the 3 feedback effects of the variation of geophysical surface on the atmosphere and the WAM 4 system are also revealed by the study. 


\section{Acknowledgements}

This work was performed within the framework of the AMMA project. Based on a French initiative, AMMA has been constructed by an international group and is currently funded by large number of agencies, especially from France, the UK, the US and Africa. It has been the beneficiary of a major financial contribution from the European Community's Sixth Framework Research Programme. Detailed information on the scientific coordination and funding is available on the AMMA international web site (https://www.amma-eu.org/). 


\section{References}

Ag Mahmoud M., 1992. Le haut Gourma Central (second edition), edited by R. Le Floc'h, CEFE/CNRS, Montpellier, $133 \mathrm{pp}$.

Anyamba, A,Tucker, C.J., 2005, Analysis of Sahelian vegetation dynamics using NOAAAVHRR NDVI data from 1981-2003. Journal of Arid Environments, 63, 596-614.

Bain, C.L, Parker, D.J., Taylor, C.M., Kergoat, L., Guichard, F., 2009, Observations of the Nocturnal Boundary Layer associated with the West African Monsoon, Monthly Weather Review, in revision.

Baret, F., Weiss, M., Garrigues, S., Allard, D., Guinot, J.P., Leroy, M., Jeanjean, H., Bohbot, H., Bosseno, R., Dedieu, G., Di Bella, C., Espana, M., Gond, V., Gu, X.F., Guyon, D., Lelong C., Mougin, E., Nilson, T., Veroustraete, F., Vintilla, R., 2009. VALERI : a network of sites and a methodology for the validation of medium spatial resolution land satellite products. Remote Sens. Environ., Revised paper.

Baup, F., Mougin, E., de Rosnay, P., Timouk, F., Chênerie, I., 2007. Surface soil moisture estimation over the AMMA Sahelian site in Mali using ENVISAT/ASAR data. Remote Sensing of Environment, 109(4), 473-481.

Boudet G., 1972. Désertification de l'Afrique tropicale sèche. Adansonia, ser. 2, 12, 4 : 505 52417

Boudet G., 1977. Désertification ou remontée biologique au Sahel. Cahiers ORSTOM, série biologie, 12: 293-300.

Bourn, D., Wint, F., 1985. Wet season distribution and abundance of livestock populations and human habitants in the Gourma region of Mali. Resource Inventory and Management, St Hellier, Jersey, UK., 53p

Brooks, N., 2006, Cultural responses to aridity in the Middle Holocene and increased social complexity, Quaternary International, 151, 29-49.

Cannadell, et al., 2002. Canadell, J.G, Steffen, W.L., and White, P.S., 2002, IGBP/GCTE terrestrial transects: Dynamics of terrestrial lecosystems under environmental change - Introduction, J. Vegetation Science, 13(3), 298-300.

Cappelaere B., Descroix L., Lebel T., Boulain N., Ramier D., Laurent J.-P., Boubkraoui S., Boucher M., Bouzou Moussa I., Chaffard V., Favreau G., Hiernaux P., Issoufou H.B.A., Le Breton E., Mamadou I., Nazoumou Y., Oi M., Ottlé C., Quantin G., 2009. The AMMA-CATCH experiment in the cultivated Sahelian area of south-west Niger Investigating water cycle response to a fluctuating climate and changing environment. Journal of Hydrology, AMMA-CATCH Special Issue, doi:10.1016/j.jhydrol.2009.06.021, (this issue).

Charney, J., Stone, P.H., and Quirk, W.J., (1975), Drought in the Sahara: A biogeophysical feedback mechanism, Science, 187, 434- 435, 4175.

Delon C., D. Serça, C. Boissard, R. Dupont, A. Dutot, P. Laville, P. de Rosnay, R. Delmas 2007. Soil NO emissions modelling using Artificial Neural Network Tellus B, ILEAPS Special Issue, Vol. 59 (3), p. 502.

De Leeuw, P.N., Diarra, L., and Hiernaux, P., 1992. An analysis of feed demand and supply for pastoral livestock in the Gourma region of Mali. In R.H. Behnke Jr, I. Scoones and C. Kerven (eds) Range ecology at disequilibrium, Proc. of meeting on Savanna Development and Pasture Production, Woburn Nov 1990, ODI, London: 136-152

de Rosnay, P., Gruhier, C., Timouk, F., Baup, F., Mougin, E., Hiernaux, P., Kergoat, L., LeDantec, V., 2009. Multiscale soil moisture measurements at the Gourma mesoscale site in Mali. This issue.

Descroix, L., Mahé, G., Lebel, T., Favreau, G., Galle, S., Gautier, E., Olivry, J-C.,Albergel, J., Amogu, O., Cappelaere, B., Dessouassi, R., Diedhiou, A., Le Breton, E., Mamadou, I. Sighomnou, D., 2009. Spatio-Temporal Variability of Hydrological Regimes Around the Boundaries between Sahelian and Sudanian Areas of West Africa: A Synthesis. J. of Hydrology, AMMA-Catch special issue. doi:10.1016/j.jhydrol.2008.12.012.

Dia, A. H., Becerra, S., Gangneron, F., 2008. Crises climatiques, ruptures politiques et transformations de l'action publique environnementale au Mali, Vertigo, 8, 1, art 7. 
Dia, A. H, 2006. Décentralisation et développement local. Le cas de la vallée du Fleuve Sénégal. Thèse Doctorat, Univ. Toulouse 2, Univ. G. Berger Saint-Louis (Sénégal), décembre.

Dicko, A. K., Djire, M., 2007. Les conventions locales face aux enjeux de la décentralisation, Paris, Karthala, $280 \mathrm{pp}$.

Favreau, G., Cappelaere, B., Massuel, S., Leblanc, M., Boucher, M., Vouillamoz, J.M., Seguis, L. \& Leduc, C., 2009. Land clearing, climate variability and water resources increase in semiarid southwest Niger: a review. Water Resour. Res., 45, W00A16, doi:10.1029/2007WR006785.

Flamant, C., Knippertz, P., Parker, D., Chaboureau, J.P., Lavaysse, C., Agusti-Panareda, A., Kergoat, L., 2009. The impact of a mesoscale convective system cold-pool on the northward propagation of the inter-tropical discontinuity over West Africa, Quarterly Journal of the Royal Meteorological Society, accepted.

Frappart F., Hiernaux P., Guichard F., Mougin, E., Kergoat, L., Arjounin, M., Lavenu, F., Koité, M., Paturel, J.E., Lebel, T.. 2009. Rainfall regime over the Sahelian climate gradient in the Gourma, Mali. This issue.

Frison, P.L., Mougin, E., Hiernaux, P., 1998. Observations and interpretation of seasonal ERS wind scatterometer data over northern Sahel (Mali). Remote Sens. Environ., 63, 233-242.

Frison, P.L., Mougin, E., Jarlan, L., Karam, M.A., Hiernaux, P., 2000, Comparison of ERS wind scatterometer and SSM/I data for Sahelian vegetation monitoring. IEEE Trans. Geosci. Remote Sensing, vol. 38, n4, 1794-1803.

Gallais, J., 1975. Pasteurs et paysans du Gourma. CNRS, Paris, France, 239 p.

Gardelle, J., Hiernaux, P., Kergoat, L., Grippa, M., 2009, Evidence of an increase in pond surface between 1954-2007 in non-cultivated Sahel revealed by aerial pictures and satellite data. Submitted to Hydrology and Earth System Sciences.

Garrigues, S., R., Lacaze, F., Baret, J.T., Morisette, M., Weiss, J.E., Nickeson, R., Fernandes, S., Plummer, N.V., Shabanov, R.B., Myneni, Y., Knyazikhin, W., Yang 2008. Validation and intercomparison of global Leaf Area Index products derived from remote sensing data. J. Geophys. Res., 113, G02028, doi:10.1029/2007JG000635

Giannini, A., Biasutti, M., and Verstraete, M., 2008, A climate model-based review of drought in the Sahel: Desertification, the re-greening and climate change, Global and Planetary Change, in press

Guichard, F., Kergoat, L., Mougin, E., Timouk, F., Baup, F., Hiernaux, P., Lavenu, F., 2009. Surface thermodynamics and radiative budgets in the Sahelian Gourma. Seasonal and diurnal cycles. This issue.

Gruhier, C., de Rosnay, P., Kerr, Y., Mougin, E., Ceschia, E., Calvet, J.-C., and Richaume, P., (2008), Evaluation of AMSR-E soil moisture product based on ground measurements over temperate and semi-arid regions, Geophys. Res. Lett., 35, L10405, doi:10.1029/2008GL033330

Hein, L., De Ridder, N., 2006, Desertification in the sahel : a reinterpretation, Global Change Biology, 12, 751-758, doi: 10.1111/j.1365-2486.2006.01135.x

Heumann, B.W., Seaquist, J.W., Eklundh, L., Jonsson, P., 2007, AVHRR derived phenological change in the Sahel and Soudan, Africa, 1982-2005, Remote Sensing of Environment, 108, 4, 385-392. doi:10.1016/j.rse.2006.11.025

Hiernaux, P., 1984, Distribution des pluies et production herbacée au Sahel: une méthode empirique pour caractériser la distribution des precipitations journalières et ses effets sur la production herbacée. Premiers resultats dans le Sahel malien. Programme Document, CIPEA-ILCA, 48p.

Hiernaux, P., 1996. The crisis of Sahelian pastoralism: ecological or economic? ODI, Pastoral Development Network, Network Paper 39a20p.

Hiernaux, P., Justice, C.O., 1986. Suivi du développement végétal au cours de l'été 1984 dans le Sahel malien. Int. J. remote Sens., 11, 1515-1531. 
Hiernaux, P., Gerard, B., 1999. The influence of vegetation pattern on the productivity, diversity and stability of vegetation: The case of 'brousse tigrée' in the Sahel. Acta Oecologica, 20(3), 147-158.

Hiernaux, P., Cissé, M.I., Diarra, L., de Leeuw, P.N., 1994. Fluctuations saisonnières de la feuillaison des arbres et des buissons sahéliens. Conséquences pour la quantification des ressources fourragères. Rev. Elev. Méd. Vét. Pays Trop., 47, 117-125.

Hiernaux, P., Lassine, D., Trichon, V., Mougin, E., Soumaguel, N., Baup, F., 2009a. Woody plant population dynamics in response to climate changes from 1984 to 2006 in Sahel (Gourma, Mali). This issue.

Hiernaux, P., Mougin, E., Diarra, L., Soumaguel, N., Lavenu, F., Tracol, Y., Diawara, M., 2009b. Sahelian rangeland response to changes in rainfall over two decades in the Gourma region, Mali. This issue.

Hiernaux, P., Ayantunde A., Kalilou A., Mougin E., Gérard B., Baup F., Grippa M., Djaby B., 2009c, Resilience and productivity trends of crops, fallows and rangelands in Southwest Niger: impact of land use, management and climate changes. This issue.

Janicot S., Ali A., Asencio N., Berry G., Bock O., Bourles B., Caniaux G., Chauvin F., Deme A., Kergoat L., Lafore J.-P., Lavaysse C., Lebel T., Marticorena B., Mounier F., Redelsperger J.-L., Ravegnani F., Reeves C., Roca R., de Rosnay P., Sultan B., Thorncroft C., Tomasini M., Ulanovsky A. and ACMAD forecasters team, 2008, Large-scale overview of the summer monsoon over West and Central Africa during the AMMA field experiment in 2006. Ann. Geophys., 26, 2569-2595.

Jarlan L., Mazzega P., Mougin E., 2002, Retrieval of land surface parameters in the Sahel from ERS Wind Scatterometer data: a brute force method. IEEE Trans. Geosci. Remote Sensing, 40(9), 2056-2062.

Jarlan, L., Mangiarotti, S., Mougin, E., Hiernaux, P., Mazzega, P., Le Dantec, V., 2008. Assimilation of SPOT/VGT-NDVI data into a Sahelian grassland model. Remote Sens. of Environ., 112, 1381-1394. doi:10.1016/j.rse.2007.02.041.

Kassibo, B. (ed.), 1997." La décentralisation au Mali : état des lieux ", LIT VERLAG Münster, Hamburg, APAD, Bulletin $n^{\circ} 14$.

Lebel, T., A., Ali, 2009. Recent trends in the Central and Western Sahel rainfall regime (1990 - 2007). J. Hydrol., this issue.

Lebel, T., Cappelaere B., Galle S., Hanan N.P., Kergoat L., Levis S., Vieux B., Descroix L., Gosset, M., Mougin, E., Peugeot, C., Seguis, L., 2009, AMMA-CATCH studies in the Sahelian region of West-Africa: an overview. doi:10.1016/j.jhydrol.2009.03.020, this issue.

Lokupitiya, R.S., Zupanski, D., Denning, A.S., Kawa, S.R., Gurney, K.R., Zupanski, M., 2008. Estimation of global $\mathrm{CO}_{2}$ fluxes at regional scale using the maximum likelihood ensemble filter. JGR., 113, D20110, doi:10.1029/2007JD009679.

Lo Seen, D., Mougin, E., Rambal, S., Gaston, A., Hiernaux, P., 1995. A regional Sahelian grassland model to be coupled with multispectral satellite data. II. Towards the control of its simulations by remotely sensed indices. Remote Sens. Environ., 52, 194-206.

Mangiarotti, S., Mazzega, P., Jarlan, L., Mougin, E., Baup, F., Demarty, J., 2008. Evolutionary bi-objective optimization of a semi-arid vegetation dynamics model with NDVI and $\sigma^{\circ}$ satellite data. Remote Sens. of Environ., 112, 1365-1380, doi:10.1016/j.rse.2007.03.030.

Morisette, J.T., and 29 co-authors, 2006. Validation of global moderate-resolution LAI products: a framework proposed within the CEOS Land Product Validation subgroup. IEEE Transanctions on Geoscience and Remote Sensing, 44(7), 1804 - 1817.

Mougin, E., Demarez, V., Hiernaux, P., Diawara, M., Berg, A., 2009. Seasonal variation of LAI, fAPAR and FCover of a Sahelian grassland in Mali. Submitted to Agricultural and Forest Meteorology.

Myneni, R.B., Hoffman, S., Knyazikhin, Y., Privette, J.L., Glassy, J., Tian, Y., Wang, Y., Song, X., Zhang, Y., Smith, G.R., Lotsch, A., Friedl, M., Morisette, J.T., Potava, P., Nemani, R.R., Running, S.W., 2002. Global products of vegetation leaf area and 
fraction absorbed PAR from year one of MODIS data. Remote Sens. Environ., 83 (1), 214-231.

Olsson, L., Eklundh, L., Ardö, J., 2005, A recent greening of the Sahel-trends, patterns and potential causes, Journal of Arid Environments, 63, 556-566. doi:10.1016/j.jaridenv.2005.03.008

Prince, S.D., 1991, Satellite remote sensing of primary production: comparison of results for Sahelian grasslands 1981-1988. International Journal of Remote Sensing, 12, 13011311.

Prince SD, Wessels KJ, Tucker CJ, Nicholson SE, 2007, Desertification in the Sahel: a reinterpretation of a reinterpretation, Global Change Biology, 13, 1308-1313, doi: 10.1111/j.1365-2486.2007.01356.x

Redelsperger, J.-L., Thorncroft, C.D., Diedhiou, A., Lebel, T., Parker, D.J., and Polcher, J., 2006, African monsoon multidisciplinary analysis - An international research project and field campaign, Bull. Am. Meteorol. Soc., 87, 1739-1746.

RIM, 1987. Refuge in the Sahel. Resource Inventory and Management, St Hellier, Jersey, UK, 115p.

Samain, O., Kergoat, L., Hiernaux, P., Guichard, F., Mougin, E., Timouk, F., Lavenu, F., 2008. Analysis of the in-situ and MODIS albedo variability at multiple time scales in the Sahel. JGR Atmosphere, 113, D14119, doi:10.1029/2007JD009174.

Stebbing, E.P., 1935, The Encroaching Sahara : the threat to the West African colonies. The Geographical Journal 85, 506-524

Thébaud, B., 2002. Foncier pastoral et gestion de l'espace au Sahel. Karthala, Paris, 318 pp.

Timouk, F., Kergoat, L., Mougin, E., Lloyd, C., Ceschia, E., de Rosnay, P., Hiernaux, P., Demarez, V., Taylor, C.M., 2009. Response of sensible heat flux to water regime and vegetation development in a central Sahelian landscape. this issue.

Tucker, C.J., Dregne, H.E., and Newcomb, W.W., 1991, Expansion and Contraction of the Sahara Desert from 1980 to 1990, Sicence, 253, 5017, 299-300

Zhou, L., Dickinson, R. E., Tian, Y., Vose, R. S., Dai, Y., 2007. Impact of vegetation removal and soil aridation on diurnal temperature range in a semiarid region: Application to the Sahel. PNAS, 104 (46), 17937-17942.

Zine, S., Jarlan, L., Frison, P.L., Mougin, E., Hiernaux, P., Rudant, J.P., 2005. Land surface parameter monitoring with ERS scatterometer data over the Sahel: A comparison between agro-pastoral and pastoral areas. Remote Sensing of Environment, 96, 438452.

Zribi, M., Pardé, M., de Rosnay, P., Baup, F., Mougin, E., Descroix, L., 2009. ERS Scatterometer Surface soil moisture analysis over two sites in south and north of Sahel region in Western Africa. This issue. 


\section{Figure captions}

Fig. 1: a) and c) Location of the Gourma meso-scale site $\left(14.5^{\circ}-17.5^{\circ} \mathrm{N} ; 1^{\circ}-2^{\circ} \mathrm{W}\right)$ showing the three embedded study spatial scales (Gourma meso-. Hombori super- and Agoufou, Eguerit and Kelma local- sites) superimposed on a Landsat false colour composite image. The figure shows the instrument and vegetation monitoring site networks. Green coloured surfaces correspond to savanna vegetation on sandy soils. Pink surfaces correspond to rocky and gravely surfaces like lateritic pans. Fine textured loamy soils are associated to white surfaces; b) Dominant soil types at meso-scale. Also indicated are the mean isohyets estimated during 1970-89 period (Frappart et al., this issue).

Fig. 2: Location of the instrument network and vegetation monitoring sites at the Hombori super-site $\left(15.58-15.13^{\circ} \mathrm{N}, 1.75^{\circ}-1.33^{\circ} \mathrm{W}\right)$.

Fig. 3: Location of the instrument network at the Agoufou local site $\left(15.3^{\circ} \mathrm{N}, 1.5^{\circ} \mathrm{W}\right)$.

Fig. 4: Long term rainfall anomalies at the Hombori meteorological station: a) $1920-2007$ period (mean $=373 \mathrm{~mm}$ ). The anomaly is calculated as the difference between the total amount of the year under consideration and the long term annual mean; b) Cumulative daily rainfall at Hombori during EOP (2005 - 2007).

Fig.5: Land cover map of the Hombori super-site obtained from the classification of SPOT-4 images, photo-interpretation of Landsat scenes and field observations. Land cover classes 15 belong the endorheic system with local sheet run-off. Classes $6-10$ belong to the endorheic system with concentrated run-off in structured watersheds.

Fig. 6: Eddy covariance flux station at the Agoufou local site (August 2005).

Fig. 7: Evaluation of satellite products during EOP (2007): a) MODIS albedo, b) Normalised AMSR-E volumetric Surface Soil Moisture (SSM), c) MODIS Leaf Area Index (LAI).

Fig. 8: Comparison of the seasonal variation of net radiation observed at Agoufou $\left(15.3^{\circ} \mathrm{N}\right.$, $\left.1.5^{\circ} \mathrm{W}\right)$ and Bamba $\left(17.1^{\circ} \mathrm{N}, 1.4^{\circ} \mathrm{W}\right)$ during 2007 . Also are indicated the daily rainfalls for the two sites.

Fig. 9: Variation of vegetation production across the Gourma gradient: a) mean herbaceous mass measured at the end of the growing season over 1984-2006, b) temporal variation index (mean of the site coefficient of variation of the mass mean), plotted against the latitude position of the sites sorted by soil types.

Fig. 10: Seasonal variation of surface variables at the Agoufou local site during EOP (2007) from 30 May to 27 October: a) Daily rainfall and soil water content in the rooting zone (0 to 1 meter depth), b) Total (herbaceous + trees) Leaf Area Index (LAI); from 28 August to 10 Septembre: c) Sensible and Latent fluxes, d) $\mathrm{CO}_{2}$ flux.

Fig. 11: Inter-annual variations of vegetation herbage mass at Agoufou during EOP (20052007). Uncertainties on mass values are $15 \%$.

Fig. 12: Comparison of aerial photographs and high resolution satellite images recorded over the Agoufou pond at the end of the raining season in 1966 (CORONA satellite image), 1996 (aerial photograph) and 2006 (SPOT satellite image).

Fig. 13: Long term anomalies of the surface extent of the Agoufou pond over the period 1954-2007. Estimation of the maximum annual extent is based on the use of aerial, high (SPOT and Landsat) or intermediate (MODIS) resolution satellite images. 
1 Fig. 14: Long term tree cover variation for 3 vegetation sites at the Hombori super-site showing increasing (\# 21), overall constant (\# 17) and decreasing (\# 31) trends. On the central plots, blue and red symbols correspond to live and dead trees, respectively (after Hiernaux et al., 2009a, this issue). Aerial images show the variation of tree density on the different sites between a) October 1984 (\# 17) or 1985 (\# 21, 31) and b) March 2007 (\# 17, 21, 31).

Fig. 15: Comparative photographs of the same vegetation sites as in Fig. 14, showing the variation in the tree population, taken in a) 1985 (\#17, 31) or 1988 (\# 21) and b) 2005 (\# 31) or 2007 (\# 17, 21).

Fig. 16: Long term anomalies at the Hombori super-site over the period $1984-2007$ of a) Rainfall Index, b) herbage production Index. Estimated vegetation anomalies are based on measurements made on 3 vegetation sites located on sandy soils (after Hiernaux et al., 2009b, this issue). 
2 Table 1 Characteristics of the land cover types mapped over the Hombori super-site: 3 relative areas (\%) of bare soil patches, of canopy cover by woody plants and area cropped, 4 and indication of main woody plant species encountered.

6

\begin{tabular}{|c|c|c|c|c|}
\hline $\begin{array}{l}\text { Land cover } \\
\text { types }\end{array}$ & $\begin{array}{l}\text { Bare soil } \\
\text { patches } \\
(\%)\end{array}$ & $\begin{array}{l}\text { Woody } \\
\text { plant } \\
\text { cover } \\
(\%)\end{array}$ & Dominant woody species & $\begin{array}{l}\text { Cropped } \\
\text { field } \\
\text { area } \\
(\%)\end{array}$ \\
\hline Bare sands & $>80$ & $<0.5$ & $\begin{array}{l}\text { Leptadenia pyrotechnica, Balanites aegyptiaca, } \\
\text { Acacia raddiana }\end{array}$ & 0 \\
\hline Sand dune & $<20$ & $2-10$ & $\begin{array}{l}\text { Acacia raddiana, Combretum glutinosum, B. } \\
\text { aegyptiaca, A. Senegal, L. pyrotechnica }\end{array}$ & $<5$ \\
\hline Sand sheet & $<30$ & $1-3$ & $\begin{array}{l}\text { Acacia ehrenbergiana, Boscia senegalensis, Maerua } \\
\text { crassifolia, A. raddiana, B. aegyptiaca }\end{array}$ & 0 \\
\hline Sandy plain & $<10$ & $5-15$ & $\begin{array}{l}\text { A. raddiana, } B \text {. aegyptiaca, Sclerocarya birrea, } \\
\text { Guiera senegalensis, } A \text {. laeta }\end{array}$ & $0-30$ \\
\hline Loamy sands & $<20$ & $10-30$ & $\begin{array}{l}\text { A. laeta, Sclerocarya birrea, Euphorbia balsamifera, } \\
\text { Grewia bicolor }\end{array}$ & $0-30$ \\
\hline Loamy flats & $>80$ & $<0.5$ & $\begin{array}{l}\text { A. ehrenbergiana, B. senegalensis, Calotropis } \\
\text { procera, M. crassifolia, Commiphora africana }\end{array}$ & 0 \\
\hline Clayed plain & $0-100$ & $5-80$ & $\begin{array}{l}\text { Acacia seyal, Anogeissus leiocarpus, Acacia nilotica, } \\
\text { Mitragyna inermis, B. aegyptiaca }\end{array}$ & $<5$ \\
\hline Hard pan & $>80$ & $0-5$ & $\begin{array}{l}\text { Boscia senegalensis, Combretum micranthum, } \\
\text { Pterocarpus lucens, A. ehrenbergiana }\end{array}$ & 0 \\
\hline $\begin{array}{l}\text { Schist } \\
\text { outcrop }\end{array}$ & $>80$ & $<1$ & $\begin{array}{l}\text { A. ehrenbergiana, Commiphora Africana, Maerua } \\
\text { crassifolia, Ziziphus mauritiana }\end{array}$ & 0 \\
\hline $\begin{array}{l}\text { Sandstone } \\
\text { rocks }\end{array}$ & $>80$ & $1-15$ & $\begin{array}{l}\text { Sclerocarya birrea, Acacia Senegal, Combretum } \\
\text { micranthum }\end{array}$ & $<1$ \\
\hline Mean & 41 & 9.5 & 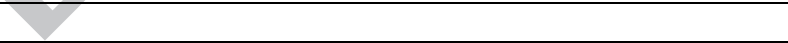 & 2.4 \\
\hline
\end{tabular}

7 
1

2

3

4

5

6

7

\begin{tabular}{|c|c|c|c|c|c|c|c|c|c|}
\hline \multirow[t]{2}{*}{$\begin{array}{l}\text { Depth } \\
\text { (cm) }\end{array}$} & \multicolumn{3}{|c|}{$\begin{array}{c}\text { Agoufou } \\
\left(15.34^{\circ} \mathrm{N}, 1.48^{\circ} \mathrm{W}\right)\end{array}$} & \multicolumn{3}{|c|}{$\begin{array}{c}\text { Eguerit } \\
\left(15.50^{\circ} \mathrm{N}, 1.40^{\circ} \mathrm{W}\right)\end{array}$} & \multicolumn{3}{|c|}{$\begin{array}{c}\text { Kelma } \\
\left(15.22^{\circ} \mathrm{N}, 1.56^{\circ} \mathrm{W}\right)\end{array}$} \\
\hline & Sand & Silt & Clay & Sand & Silt & Clay & Sand & Silt & Clay \\
\hline $0-6$ & 91.0 & 3.3 & 4.6 & 43.6 & 29,8 & 26.3 & 47.8 & 27.5 & 24.5 \\
\hline $6-12$ & 91.1 & 3.2 & 5.1 & 43.6 & 27,9 & 28.1 & 40.3 & 19.4 & 40.0 \\
\hline $12-25$ & 89.7 & 4.1 & 5.8 & 30.2 & 27,4 & 42.1 & 35.1 & 19.8 & 45.1 \\
\hline $25-50$ & 90.9 & 3.2 & 5.5 & - & - & - & 31.6 & 16.1 & 52.4 \\
\hline $50-100$ & 92.0 & 1.9 & 5.8 & - & - & - & 30.1 & 21 & 48.9 \\
\hline
\end{tabular}

Table 2 Characteristics of soil texture in terms of sand, clay and silt contents (\%) for the 3 local sites (Agoufou, Kelma and Eguerit). Particles size are defined as clay $(<0.002 \mathrm{~mm})$, silt $(<0.05 \mathrm{~mm})$, and sand (<2 mm).

8

9

10

11

12

13

14 
Table 3 General characteristics of the 3 instrumented local sites distributed within the Hombori super-site. Is also indicated the list of instruments deployed on each site (FS: Energy and $\mathrm{CO}_{2}$ Flux station; AWS: Automatic Weather Station; AR: Automatic Raingauge; ASMS: Automatic Soil Moisture Station; PARIS: PAR Interception Station; SFS: Sap Flux Station; CO2: CO2 precision station; IDAF: wet and dry deposit station; AERONET: photometer; HFS: Heat Flux Station).

\begin{tabular}{|c|c|c|c|c|c|}
\hline $\begin{array}{l}\text { Site Name } \\
\text { Location }\end{array}$ & $\begin{array}{l}\text { Soil } \\
\text { Type }\end{array}$ & Vegetation type & $\begin{array}{c}\text { Dominant herbaceous } \\
\text { species }\end{array}$ & Dominant woody species & Instrument \\
\hline $\begin{array}{l}\text { Agoufou } \\
\left(15.34^{\circ} \mathrm{N}\right. \\
\left.1.48^{\circ} \mathrm{W}\right)\end{array}$ & $\begin{array}{l}\text { Fixed } \\
\text { dunes }\end{array}$ & Open woody savannah & $\begin{array}{l}\text { Cenchrus biflorus, Aristida } \\
\text { mutabilis, Zornia glochidiata, } \\
\text { Tragus berteronianus }\end{array}$ & $\begin{array}{l}\text { Acacia raddiana, Combretum } \\
\text { glutinosum, B. aegyptiaca, } A \text {. } \\
\text { Senegal, L. pyrotechnica }\end{array}$ & $\begin{array}{l}\text { FS, AWS, AR, } \\
\text { ASMS, PARIS, } \\
\text { SFS, CO2, IDAF, } \\
\text { AERONET }\end{array}$ \\
\hline $\begin{array}{l}\text { Eguerit } \\
\left(15.50^{\circ} \mathrm{N}\right. \\
\left.1.40^{\circ} \mathrm{W}\right)\end{array}$ & $\begin{array}{l}\text { Gravels, } \\
\text { loamy } \\
\text { patches }\end{array}$ & $\begin{array}{l}\text { Scattered shrubs, } \\
\text { herbs on loamy } \\
\text { deposits }\end{array}$ & $\begin{array}{l}\text { Schoenefeldia gracilis, } \\
\text { Aristida adscentionis, } \\
\text { Pennisetum violaceum, } \\
\text { Panicum laetum }\end{array}$ & $\begin{array}{l}\text { A. ehrenbergiana, } \\
\text { Commiphora Africana, } \\
\text { Maerua crassifolia,, Ziziphus } \\
\text { mauritiana }\end{array}$ & HFS, AR, ASMS \\
\hline $\begin{array}{l}\text { Kelma } \\
\left(15.22^{\circ} \mathrm{N}\right. \\
\left.1.56^{\circ} \mathrm{W}\right) \\
\end{array}$ & $\begin{array}{l}\text { Clayed } \\
\text { soil }\end{array}$ & Open Forest & $\begin{array}{c}\text { Sporobolus hevolvus, } \\
\text { Echinochloa colona, } \\
\text { Aeschinomene sensitive }\end{array}$ & $\begin{array}{l}\text { Acacia seyal, Acacia nilotica, } \\
\text { B. aegyptiaca }\end{array}$ & $\begin{array}{c}\text { FS, AR, ASMS, } \\
\text { SFS }\end{array}$ \\
\hline
\end{tabular}


Table 4 List of measured variables at the Automatic Weather Stations.

\begin{tabular}{llll}
\hline Variable & Unit & Height $(\mathbf{m})$ & Instrument \\
\hline Incoming short wave radiation & $\mathrm{W} \mathrm{m}^{-2}$ & 2.2 & Kipp\&Zonen CNR1 \\
Outgoing short wave radiation & $\mathrm{W} \mathrm{m}^{-2}$ & 2.2 & Kipp\&Zonen CNR1 \\
Incoming long wave radiation & $\mathrm{W} \mathrm{m}^{-2}$ & 2.2 & Kipp\&Zonen CNR1 \\
Outgoing long wave radiation & $\mathrm{W} \mathrm{m}^{-2}$ & 2.2 & Kipp\&Zonen CNR1 \\
Incoming global PAR & $\mathrm{mmol} \mathrm{m}^{-2} \mathrm{~s}^{-1}$ & 2.2 & Delta T BF3 \\
Incoming diffuse PAR & $\mathrm{mmol} \mathrm{m}^{-2} \mathrm{~s}^{-1}$ & 2.2 & Delta T BF3 \\
IRT surface temperature & ${ }^{\circ} \mathrm{C}$ & 2.2 & Apogee IRTS-P \\
Wind velocity & $\mathrm{m} \mathrm{s}^{-1}$ & 2.2 & Vector A100R \\
Wind direction & ${ }^{\circ} 360$ & 2.2 & Vector W200P \\
Atmospheric pressure & $\mathrm{hPa}$ & 1 & Setra 278 \\
Air temperature & ${ }^{\circ} \mathrm{C}$ & 2 & Campbell CS215 \\
Relative humidity & $\%$ & 2 & Campbell CS215 \\
Rainfall & $\mathrm{mm}$ & 1,5 & Campbell SBS500 \\
TDR Soil moisture & $\mathrm{Ms}$ & $-0.1,-0.3,-$ & Campbell CS616 \\
& & $0.6,-0.8,-1.2$, & \\
& & $-1.5,-2.5,-$ & \\
Soil heat flux & $\mathrm{W} \mathrm{m}$ & $4.0,-5.0$ & \\
Soil temperature & ${ }^{\circ} \mathrm{C}$ & $-0,05,-0,1$ & Huskflux HFP01 \\
Soil surface temperature & ${ }^{\circ} \mathrm{C}$ & $-0,05,-0,1$ & Campbell \&08, 107 \\
PIR radiometer (MODIS, & & -0.001 & RoHS type K \\
SPOT) & $\mathrm{mol} \mathrm{m}^{-2} \mathrm{~s} \mathrm{~s}^{-1}$ & 3 & \\
R radiometer (MODIS, SPOT) & $\mathrm{mol} \mathrm{m}^{-2} \mathrm{~s}^{-1}$ & 3 & Skye SKR1850A \\
\hline
\end{tabular}


Table 5 List of monitored variables recorded at the Gourma site with automatic instruments and field campaigns.

\begin{tabular}{|c|c|}
\hline Variable & Units \\
\hline Gross Photosynthetic Productivity (GPP) & $\mathrm{gC} \mathrm{m}^{-2} \mathrm{~d}^{-1}$ \\
\hline Net Primary Productivity (NPP) & $\mathrm{gC} \mathrm{m}^{-2} \mathrm{~d}^{-1}$ \\
\hline Net Ecosystem Productivity (NEP) & $\mathrm{gC} \mathrm{m}^{-2} \mathrm{~d}^{-1}$ \\
\hline Herbaceous green standing mass (BM) & $\mathrm{gDM} \mathrm{m}^{-2}$ \\
\hline Herbaceous dry standing mass & $\mathrm{gDM} \mathrm{m}^{-2}$ \\
\hline Herbaceous litter mass & $\mathrm{gDM} \mathrm{m}^{-2}$ \\
\hline Herbaceous root mass & $\mathrm{gDM} \mathrm{m}^{-2}$ \\
\hline Herbaceous Leaf Area Index (LAI) & $\mathrm{m}^{2} \mathrm{~m}^{-2}$ \\
\hline Tree standing mass & $\mathrm{gDM} \mathrm{m}^{-2}$ \\
\hline Tree Plant Area Index (PAI) & $\mathrm{m}^{2} \mathrm{~m}^{-2}$ \\
\hline \multicolumn{2}{|c|}{ Fraction of Absorbed Photosynthetically Active Radiation (FAPAR) } \\
\hline Soil Respiration & $\mu \mathrm{molC} \mathrm{m}^{-2} \mathrm{~s}$ \\
\hline Maximum Photosynthetic Assimilation & $\mu \mathrm{molC} \mathrm{m}^{-2} \mathrm{~s}$ \\
\hline Latent heat flux & $W m^{-2}$ \\
\hline Sensible heat flux & $\mathrm{W} \mathrm{m^{-2 }}$ \\
\hline Soil heat flux & $\mathrm{W} \mathrm{m}^{-2}$ \\
\hline $\mathrm{CO} 2$ concentration (at $2 \mathrm{~m}$ ) & ppmv \\
\hline Runoff & $\mathrm{mm} \mathrm{d}^{-1}$ \\
\hline Drainage & $\mathrm{mm} \mathrm{d}^{-1}$ \\
\hline Soil Water Content & $m^{3} m^{-3}$ \\
\hline Sap flow & $\mathrm{kg} \mathrm{h}^{-1}$ \\
\hline
\end{tabular}


a)

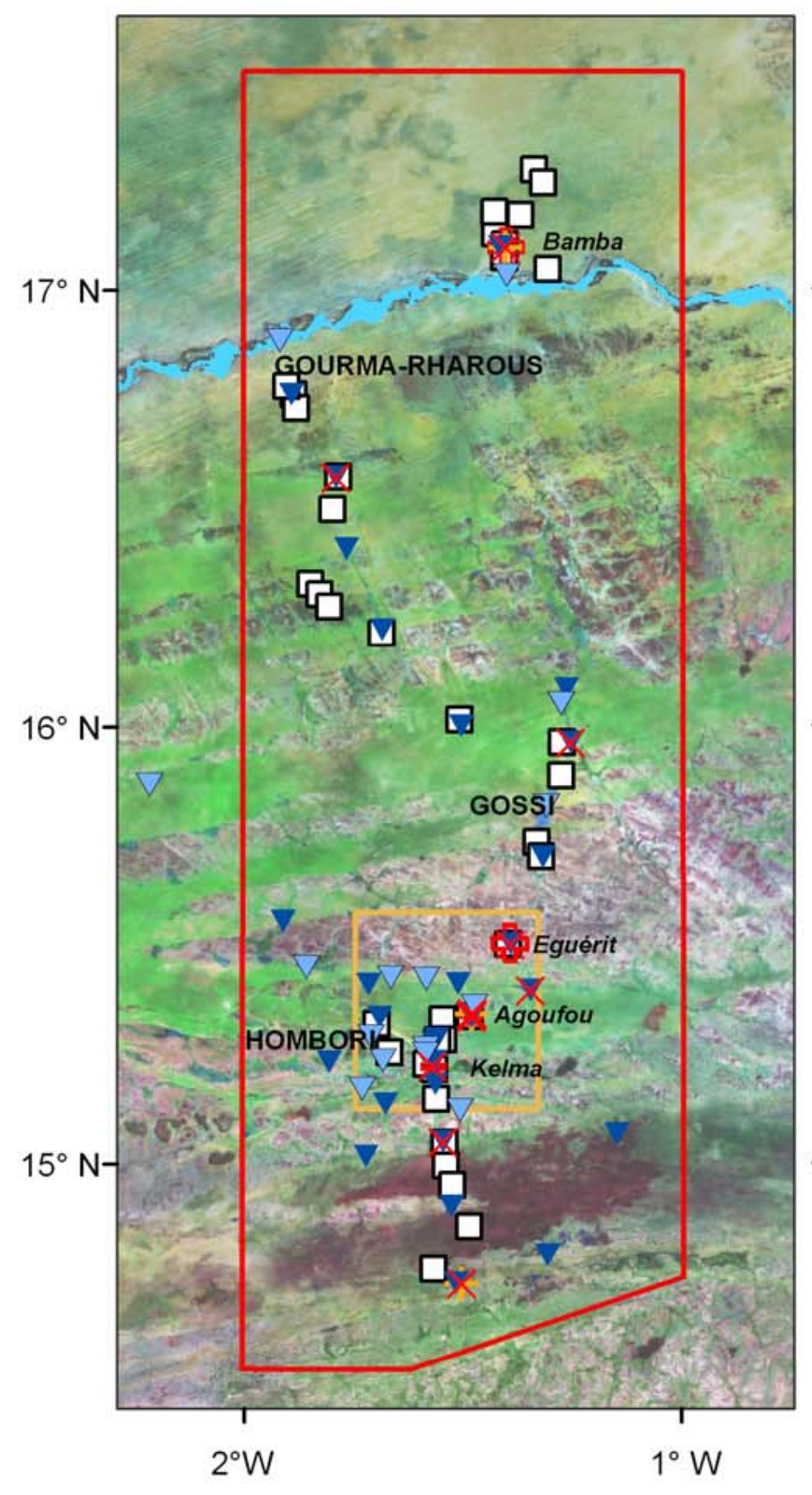

b)

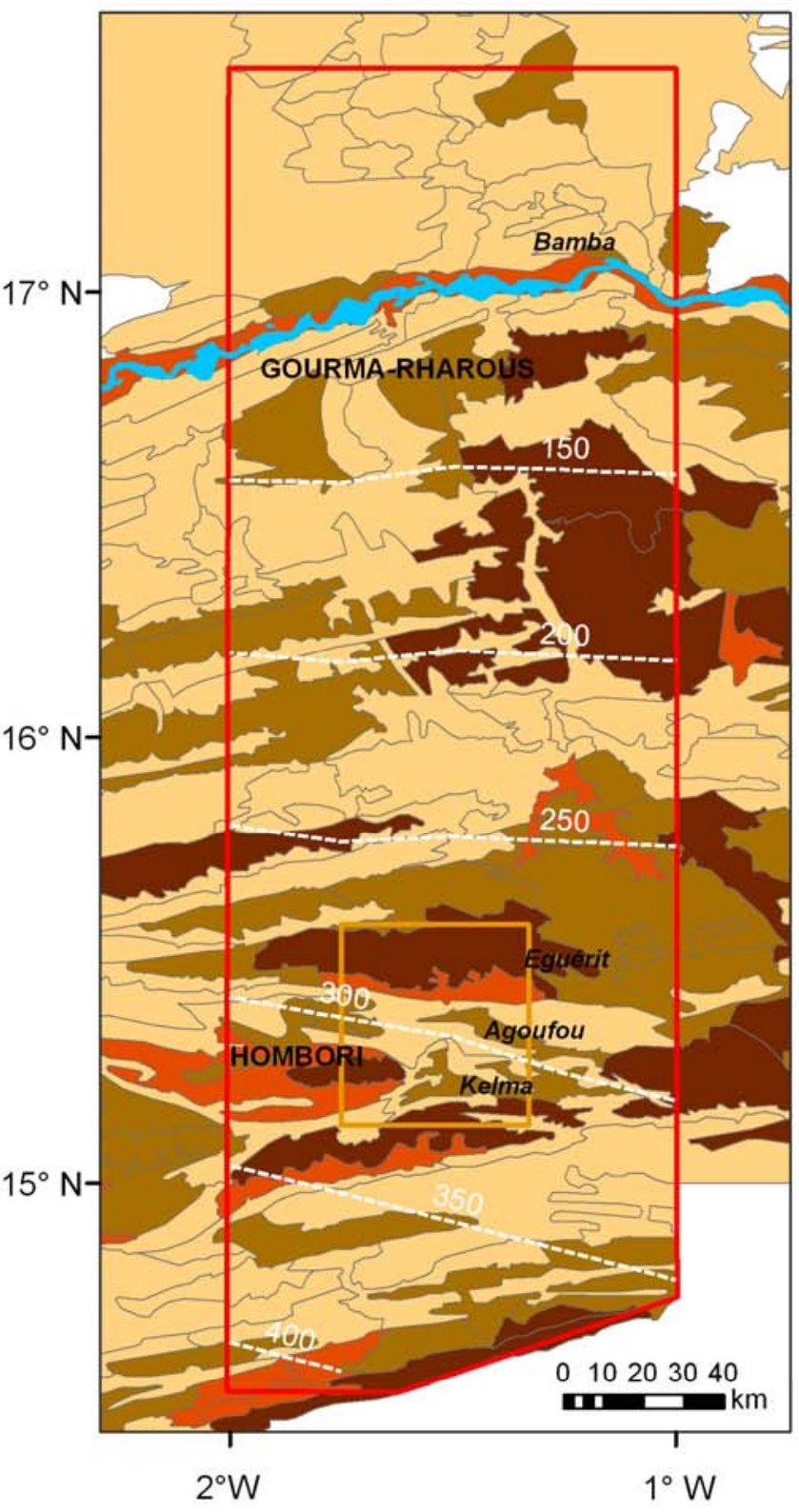

c)

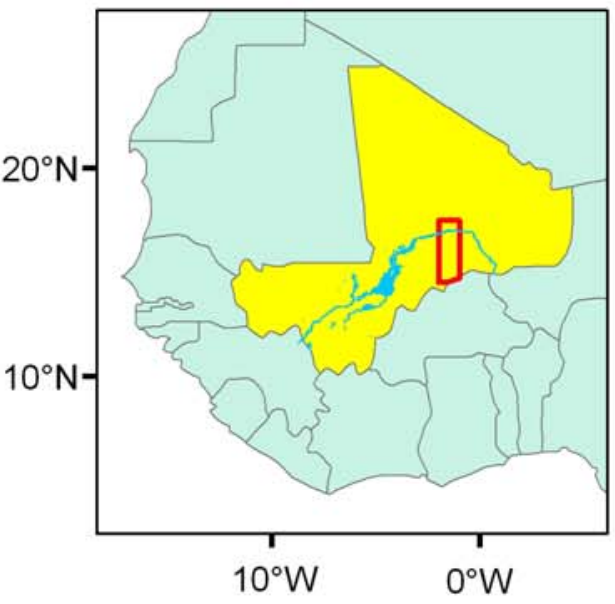

\section{Legend}

$\nabla$ raingauge

$\nabla$ automatic raingauge

+ automatic weather station

$+\mathrm{CO}_{-} \mathrm{H}_{2} \mathrm{O}$ flux station

ङ heat flux station

$\times$ soil moisture pit

$\square$ vegetation sites

$\square$ Hombori super site

Gourma mesoscale window

\section{Soil type}

$\square$ Sand

Rocks

Clay

Mosaic

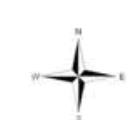

i- 
Fig.2

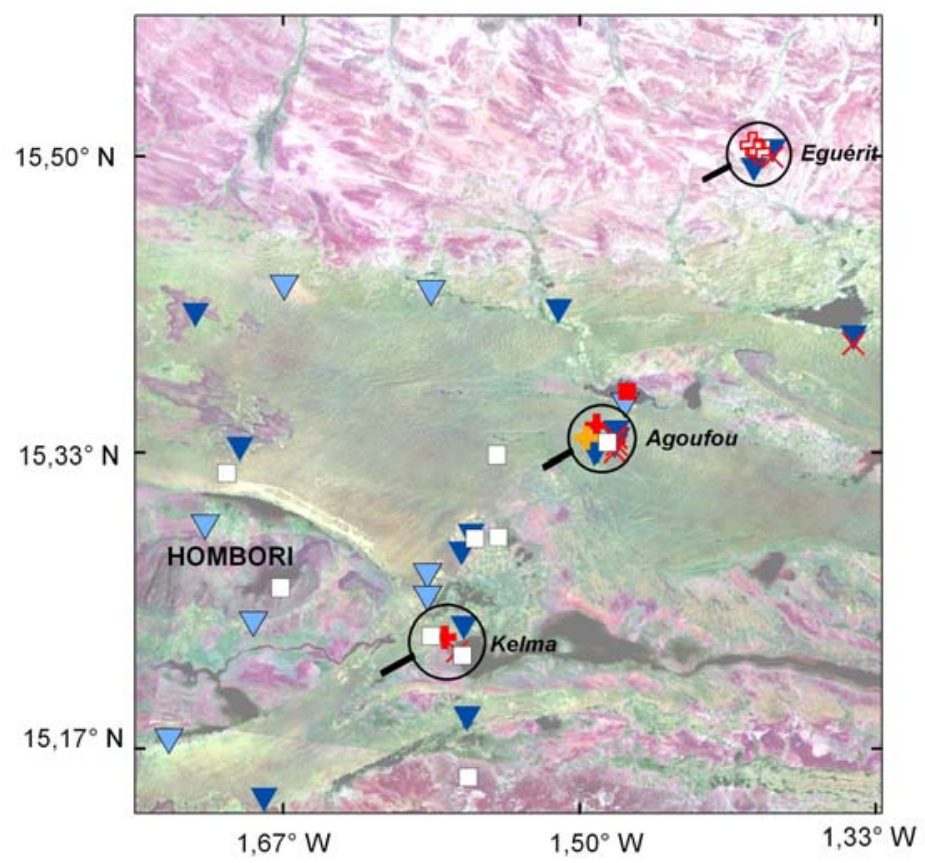

\section{Legend}

$\boldsymbol{\nabla}$ automatic raingauge

$\nabla$ raingauge

* automatic weather station

ङ heat flux station

+ $\mathrm{CO} 2 \& \mathrm{H} 2 \mathrm{O}$ flux station

$X$ soil moisture pit

$\square$ vegetation sites

- limnimeter

$\begin{array}{llll}0 & 2.5 & 5 \quad 7.5 & 10 \\ & & \end{array}$ 
Fig. 3

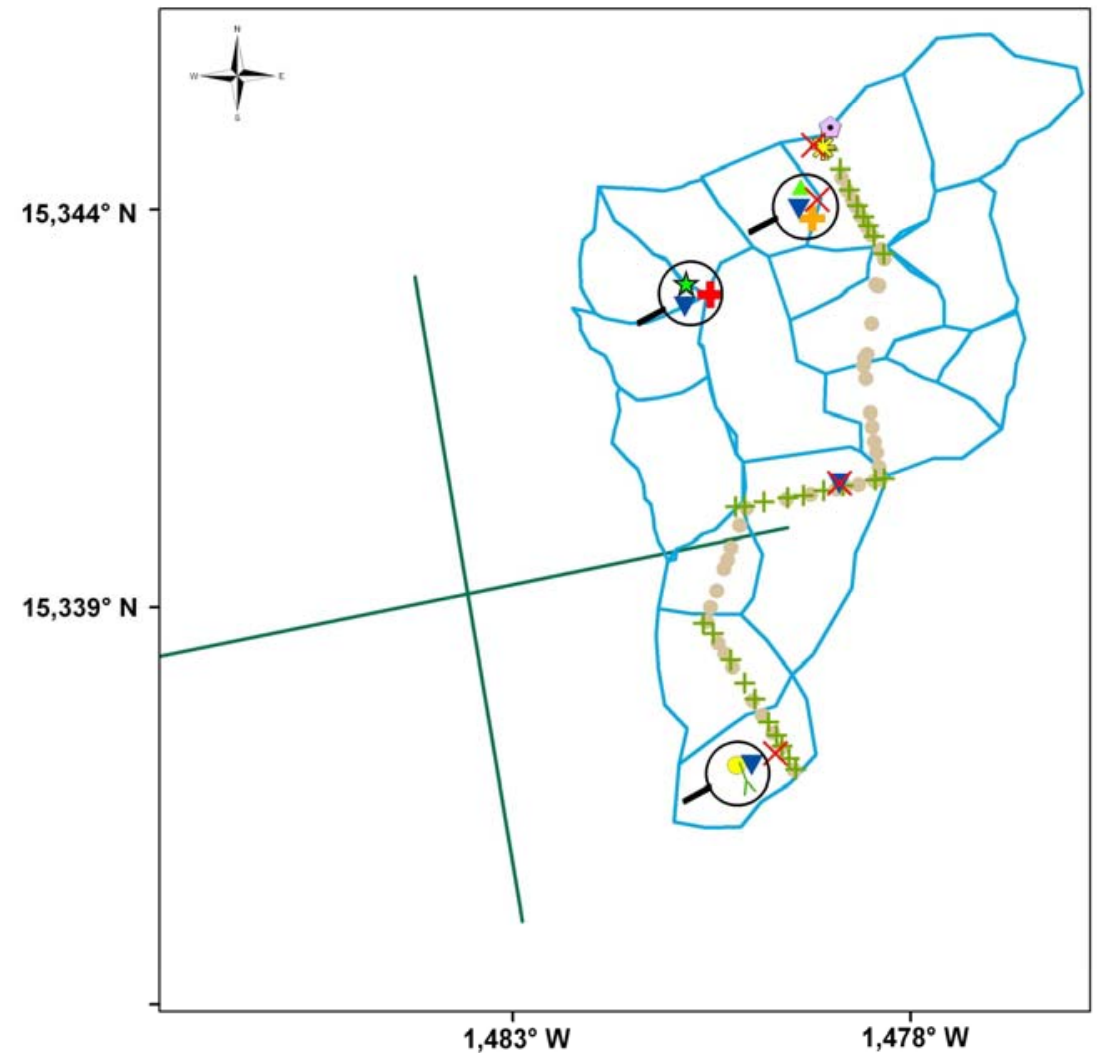

\section{Legend}

$\nabla$ automatic raingauge

$\times$ soil moisture station

$+\quad$ soil moisture probes

* automatic weather station

* $\mathrm{CO} 2$ \& $\mathrm{H} 2 \mathrm{O}$ flux station

हn AER AERET photometer

$\Delta \quad$ NDVImeter

- IDAF station

$\lambda$ sap flow station

th $\mathrm{CO} 2$ concentration station

- PAR measurements

- vegetation transect

- hydrological transect

watersheds

$\begin{array}{lllll}0 & 0,08 & 0,16 & 0,24 & 0,32\end{array}$

W 
Fig.4

Hombori (1922 - 2007)

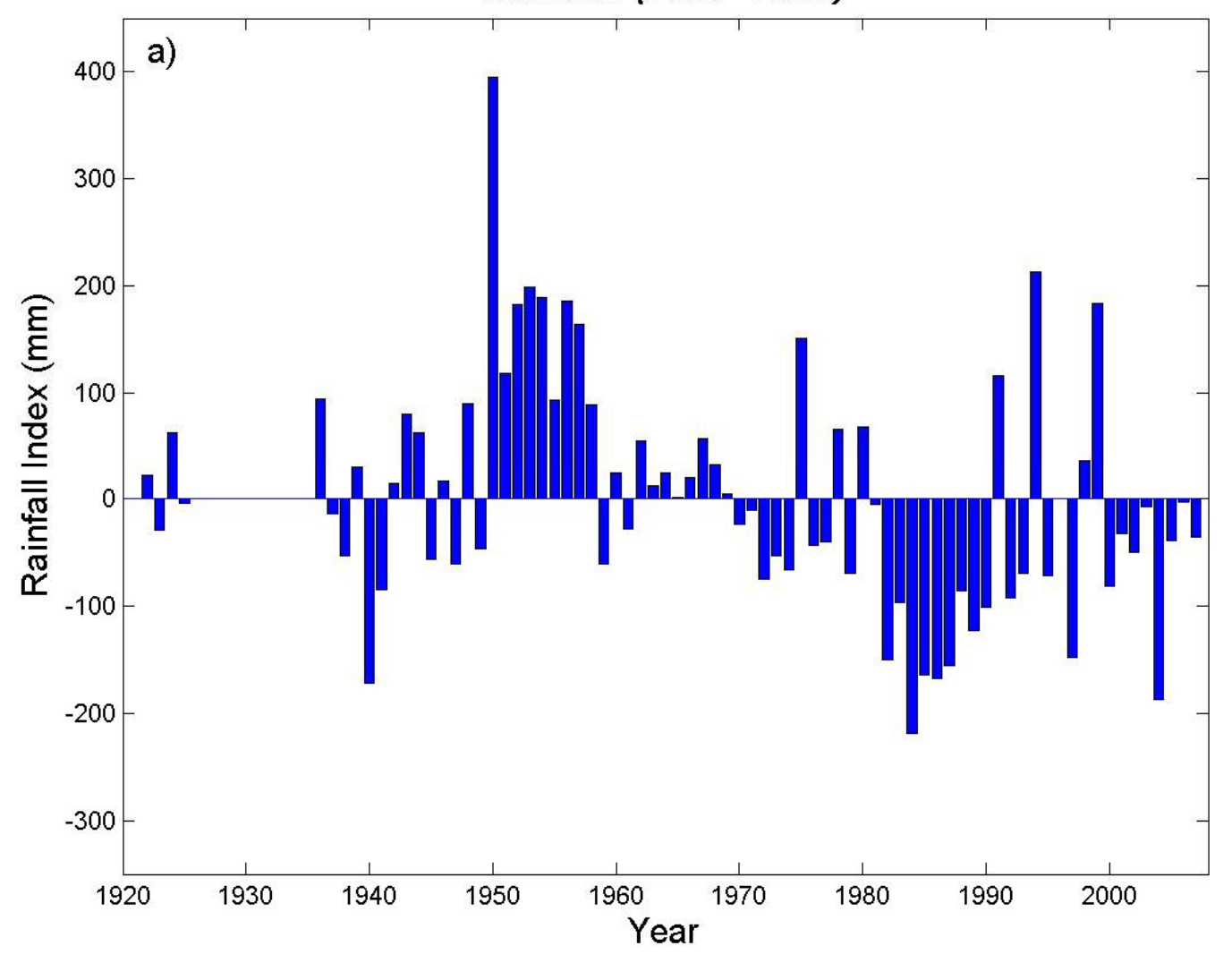




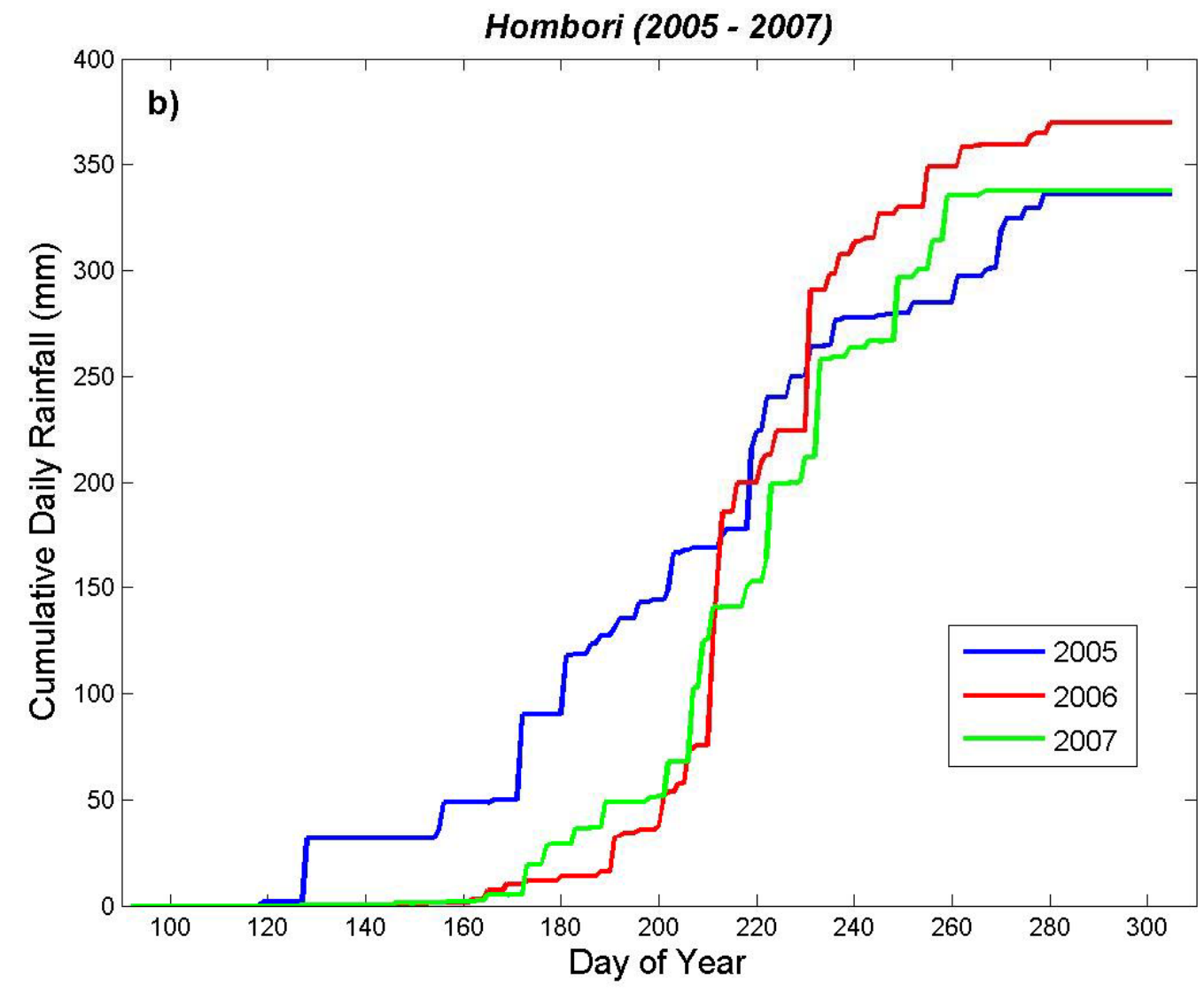



Fig. 6

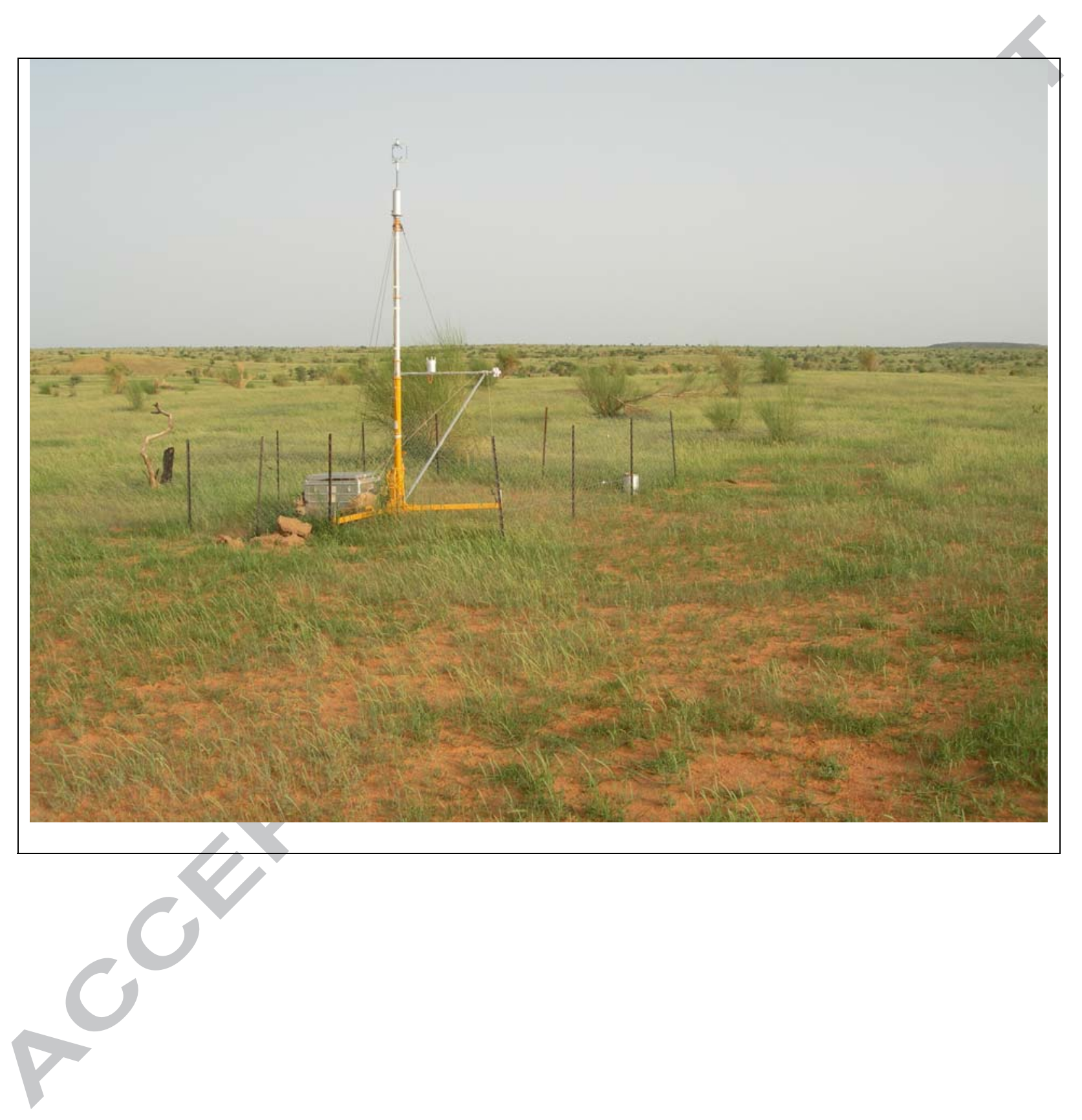


Fig. 7

(a)

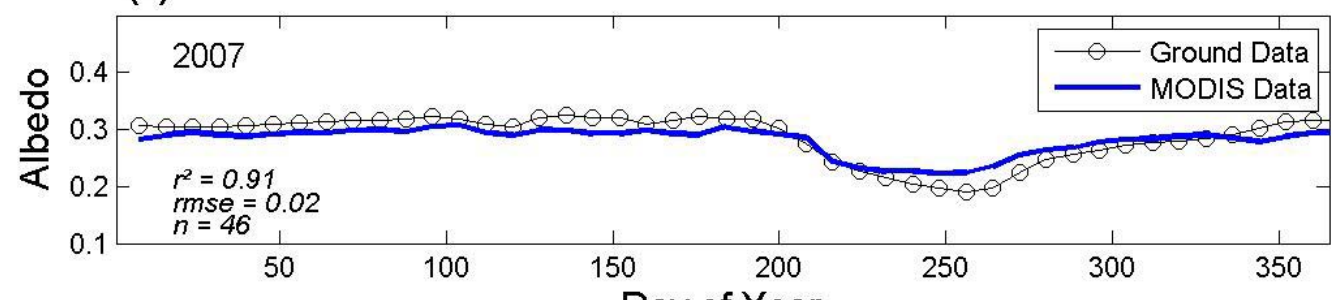

(b)
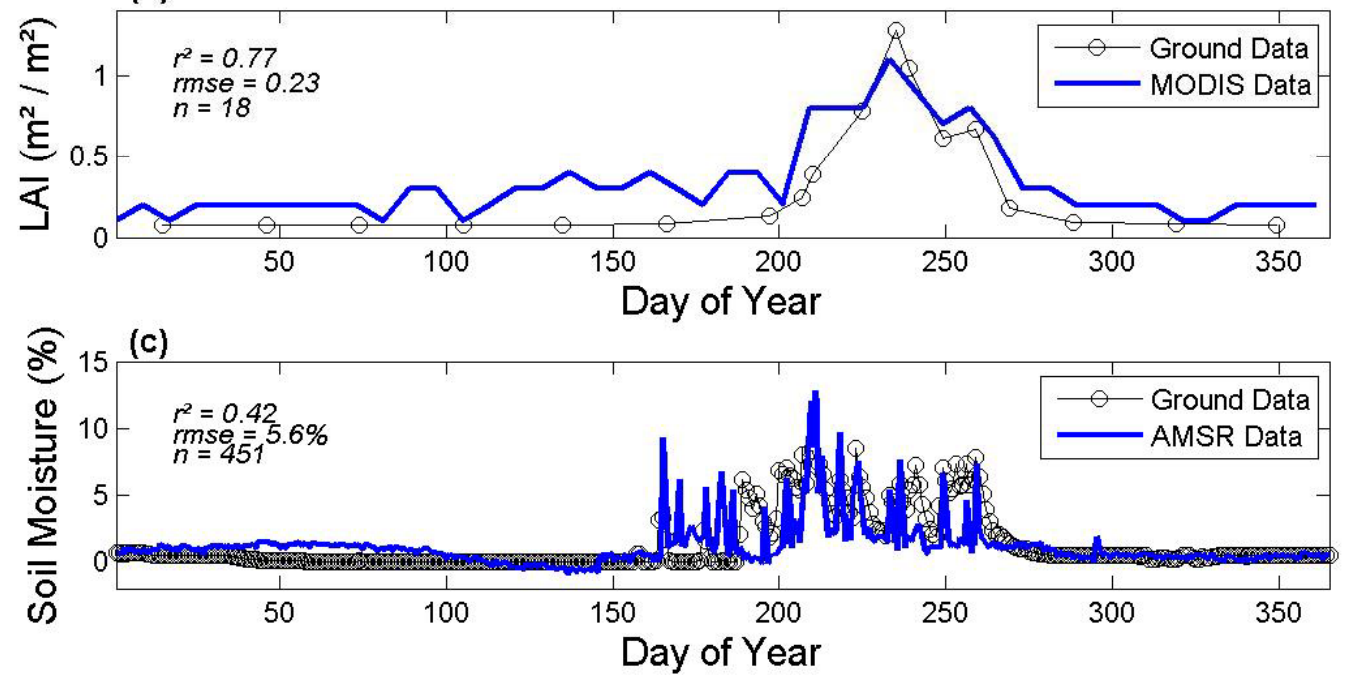
Fig. 8:

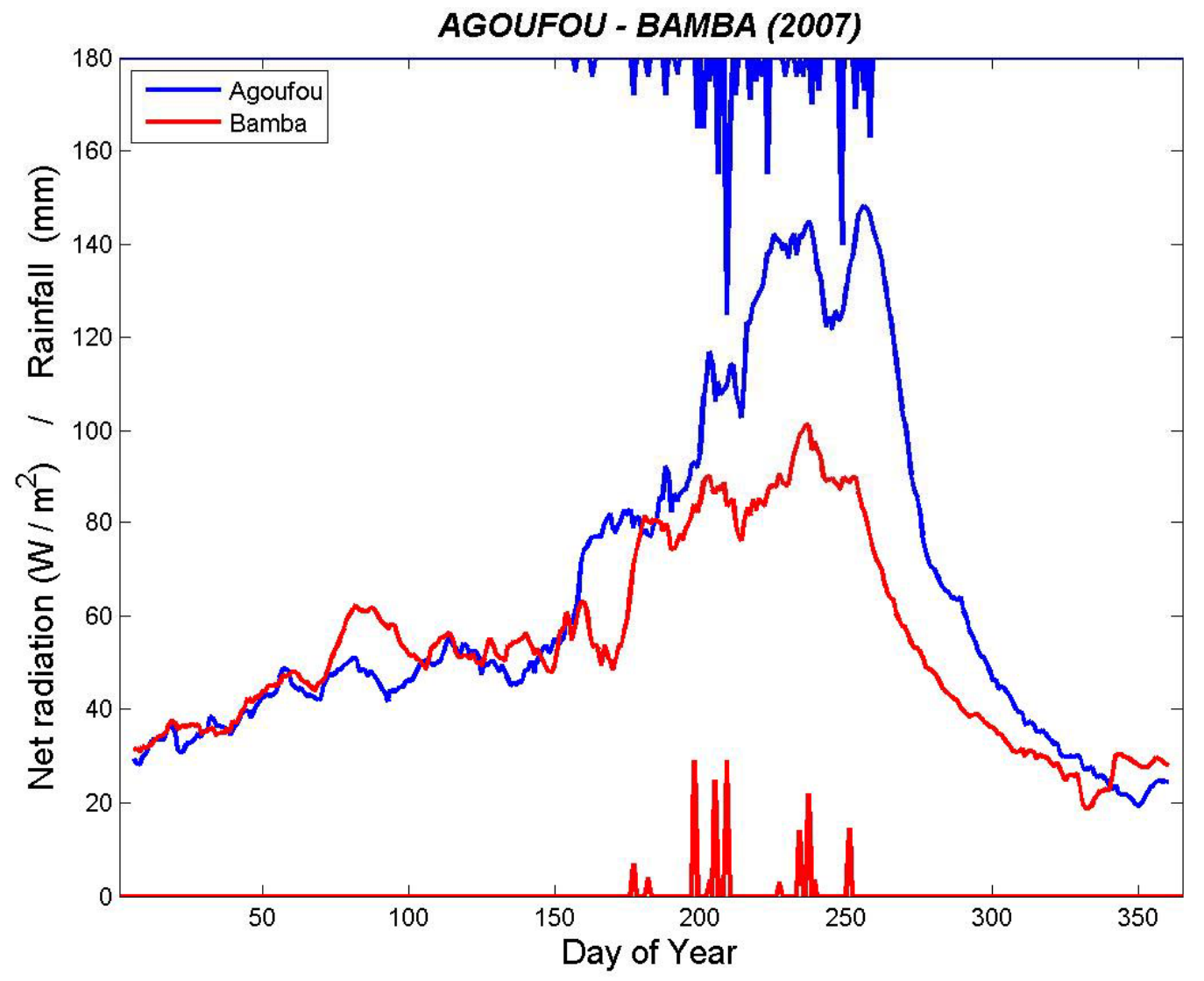


Fig. 9
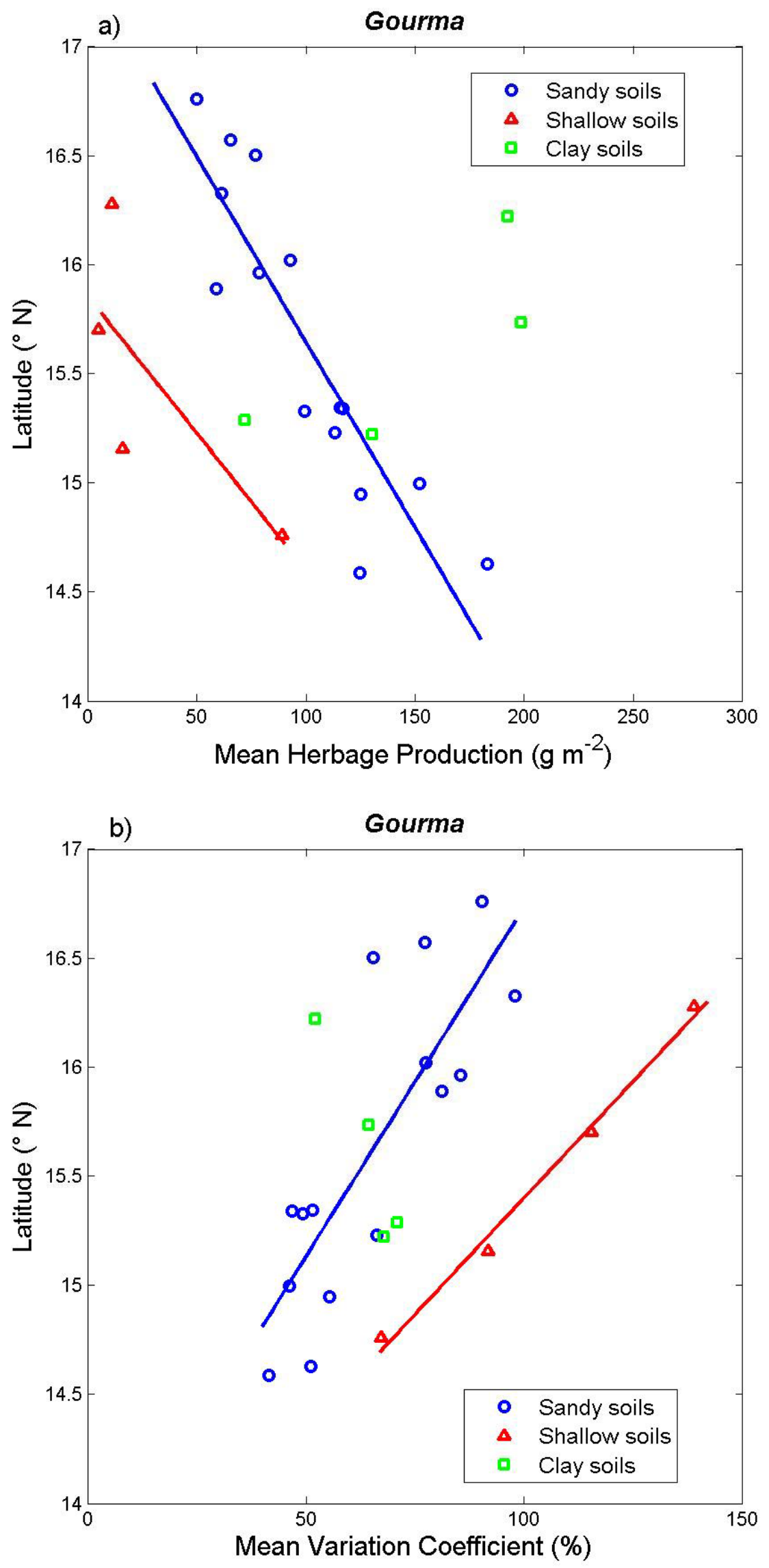
Fig. 10

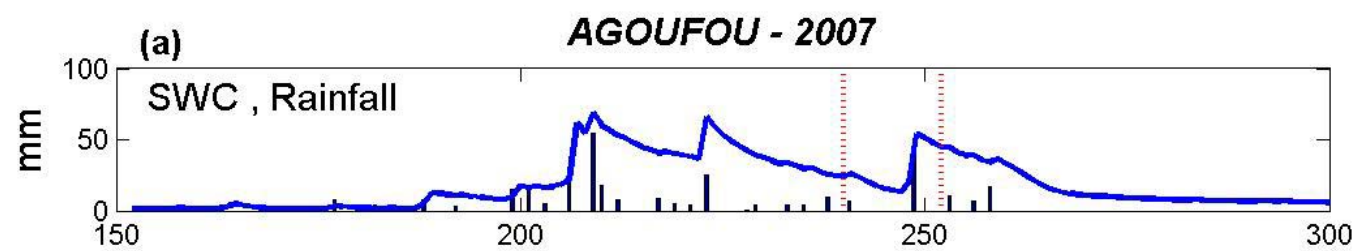

(b)
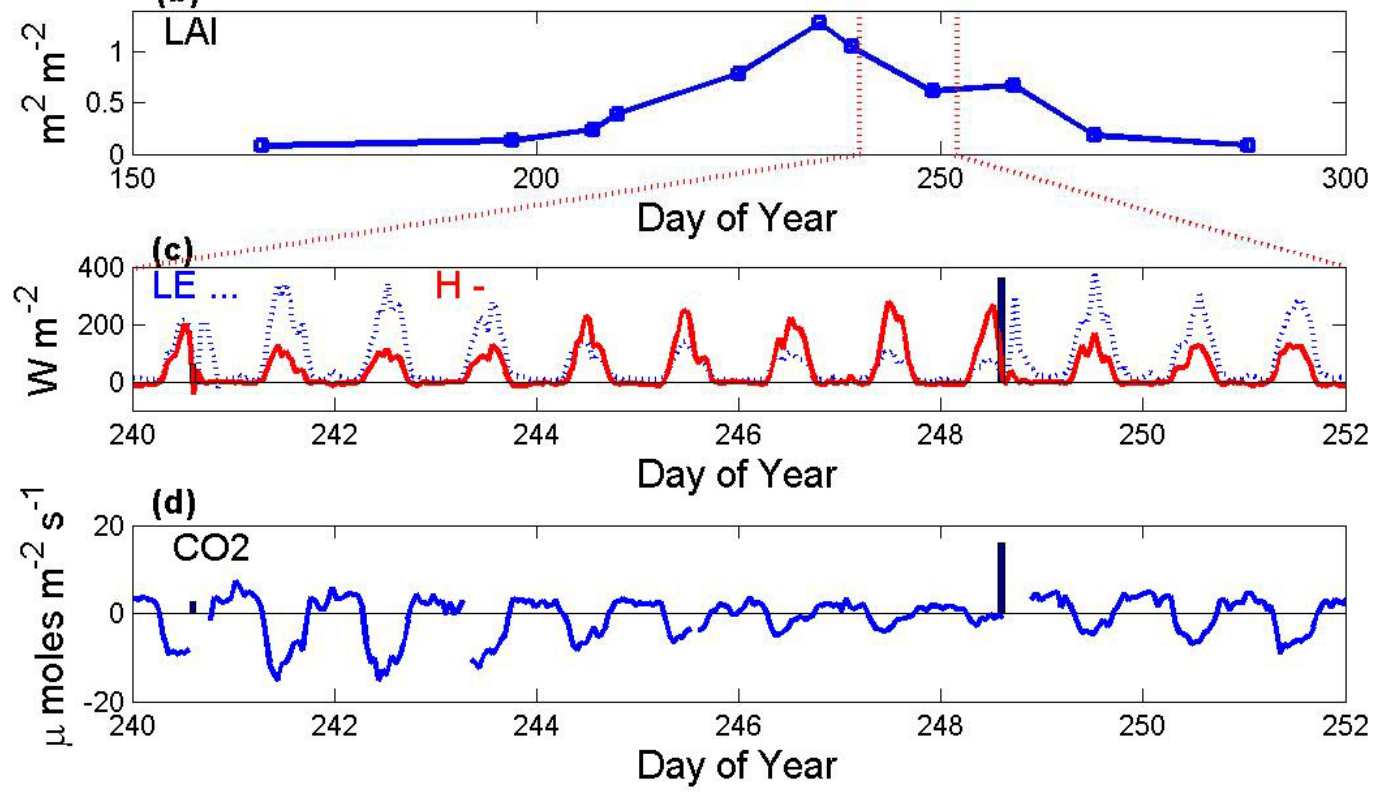
Fig. 11

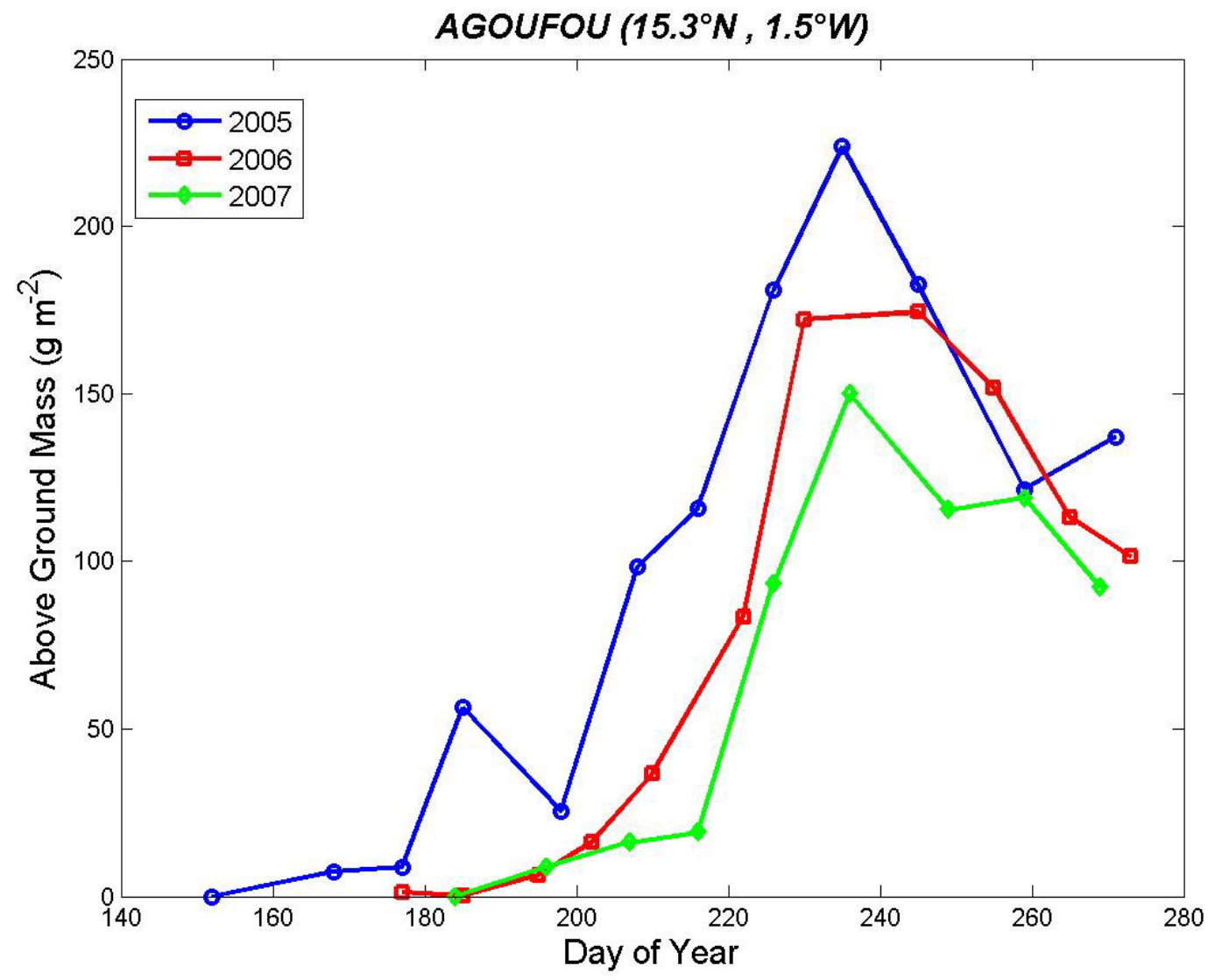


Fig. 12
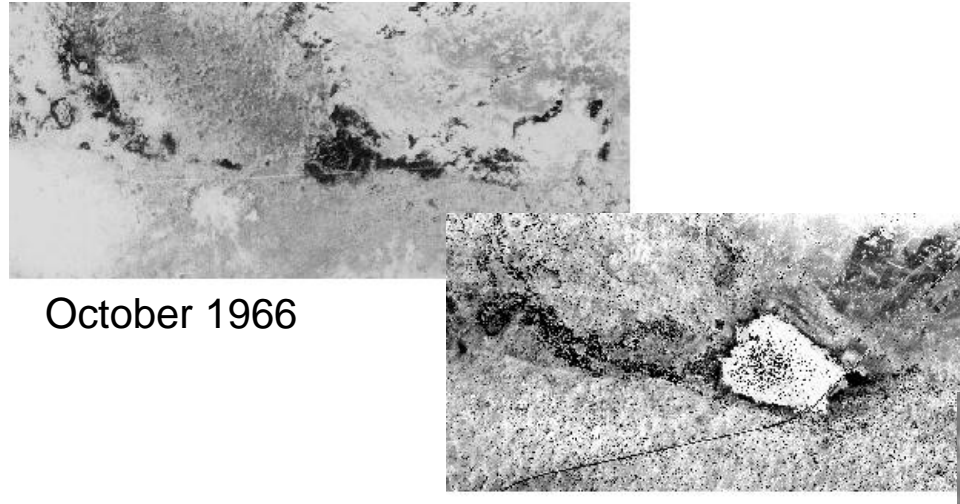

September 1996

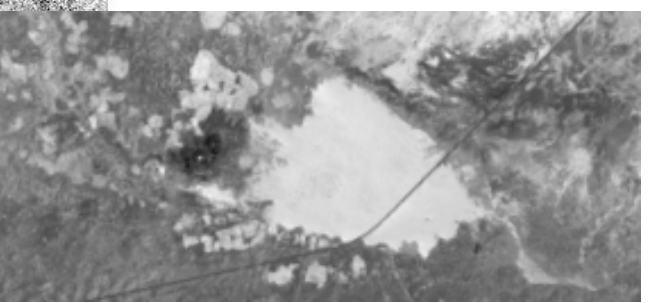

October 2006 
Fig. 13

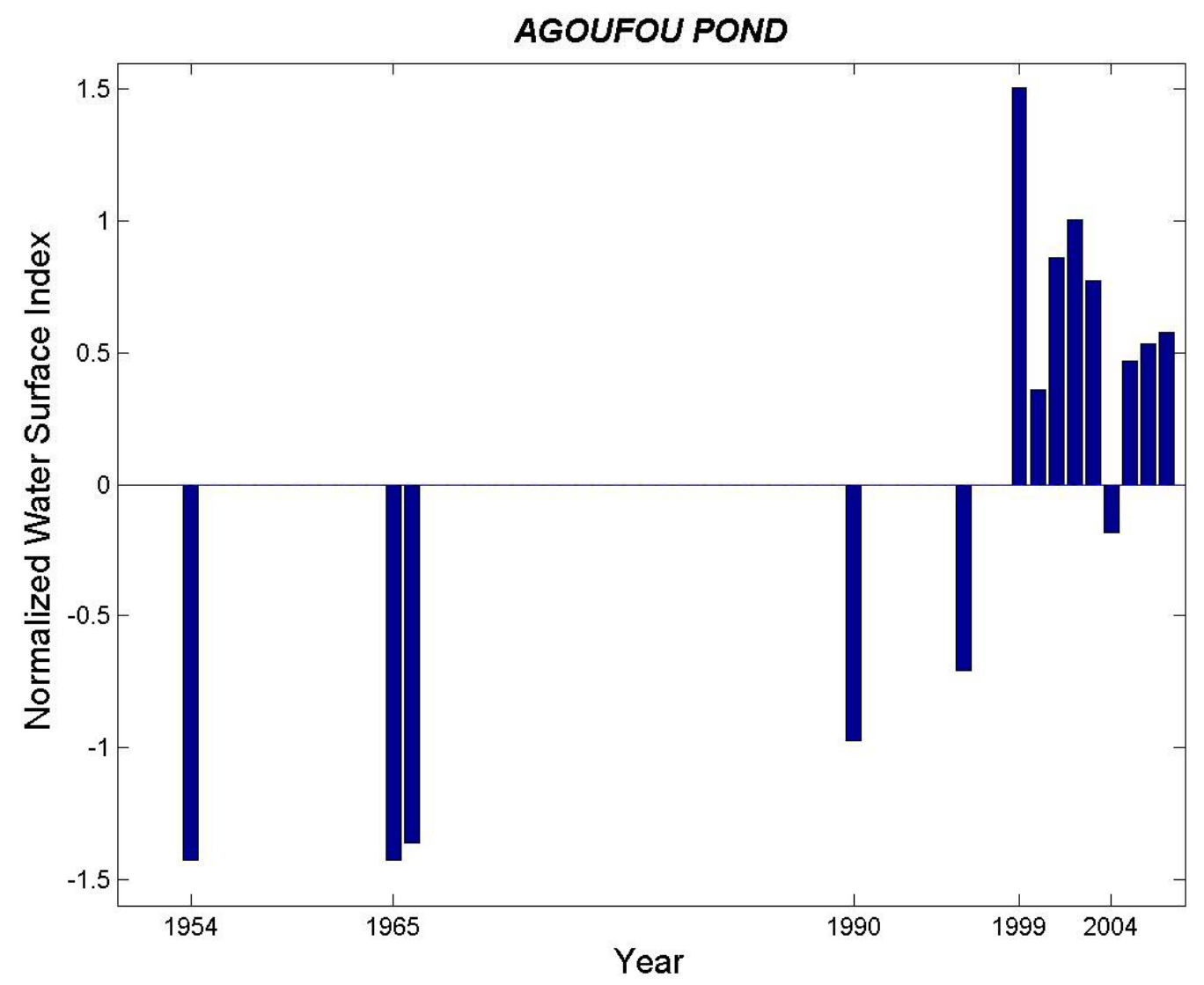


Fig. 14

a) 1984 - 1985
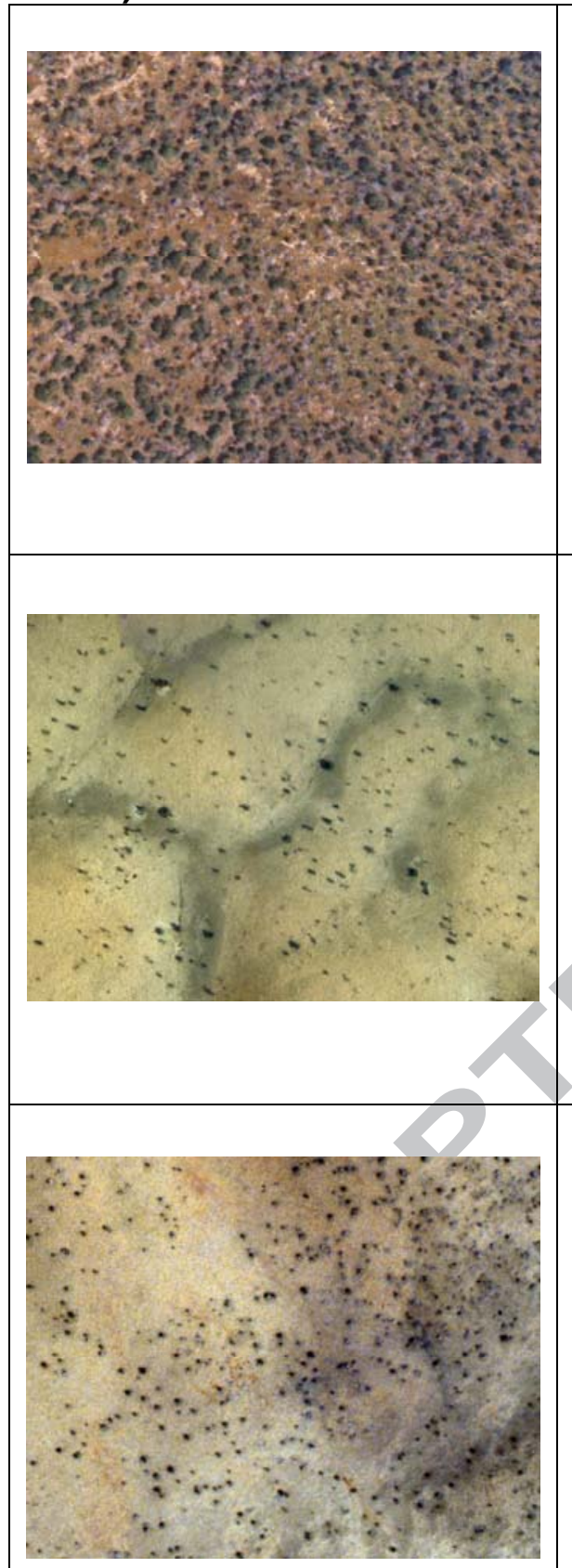

b) 2007
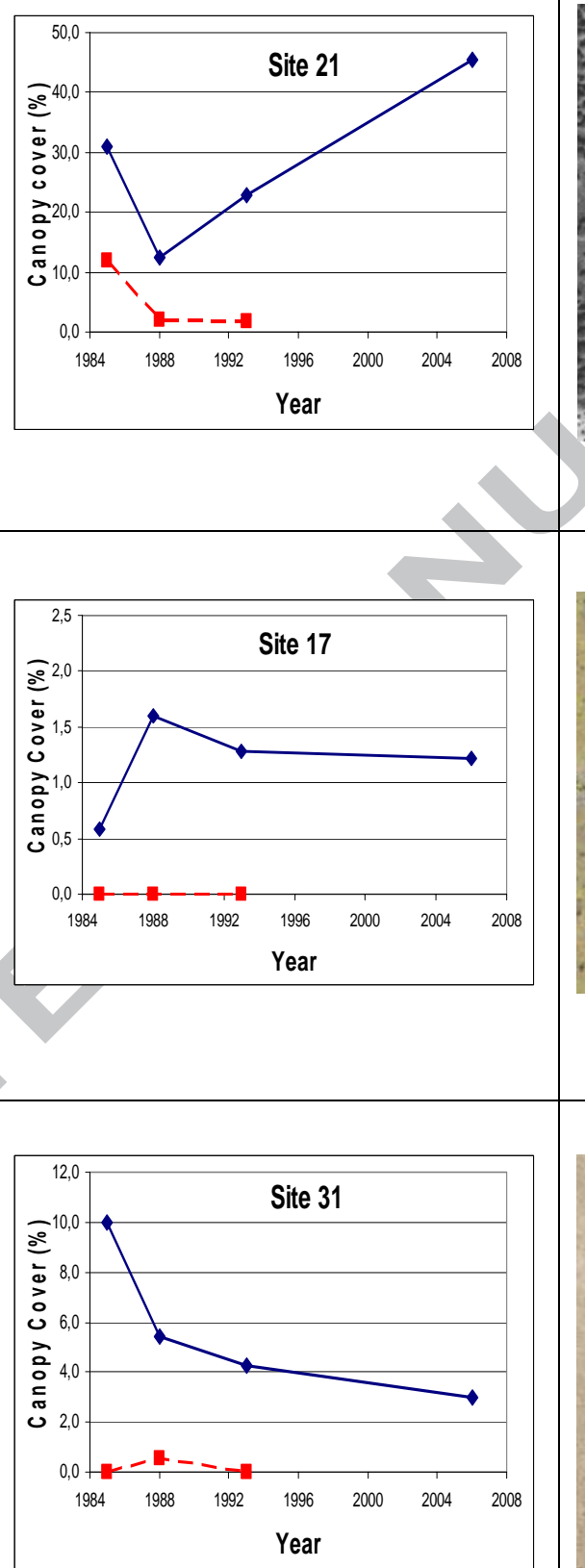
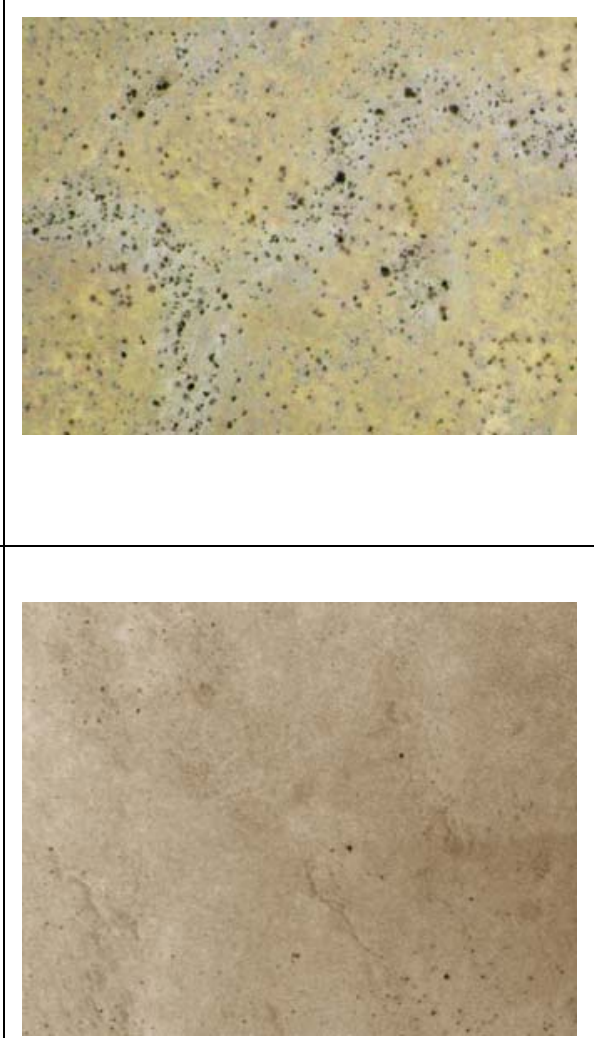
Fig. 15

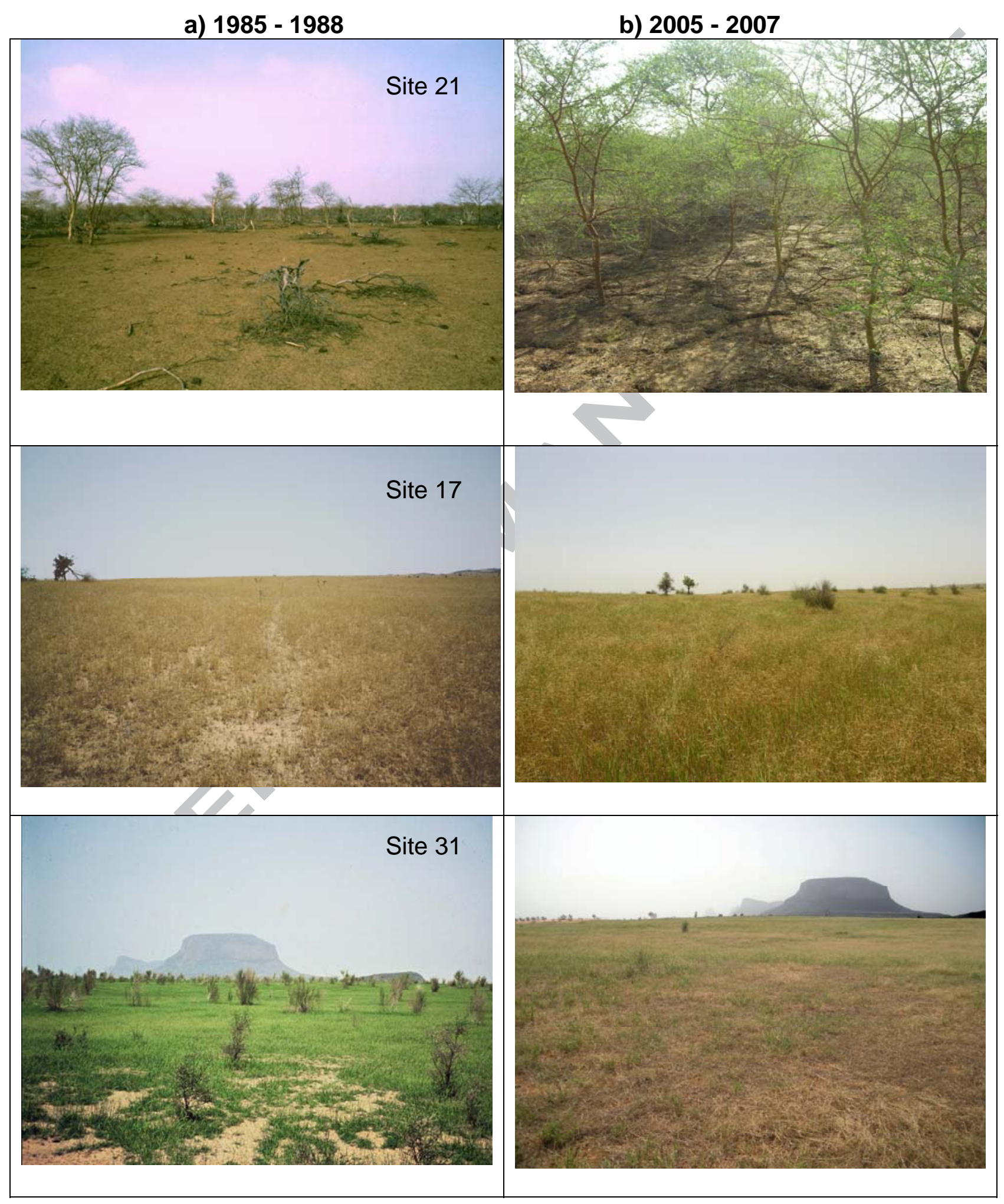


Fig. 16
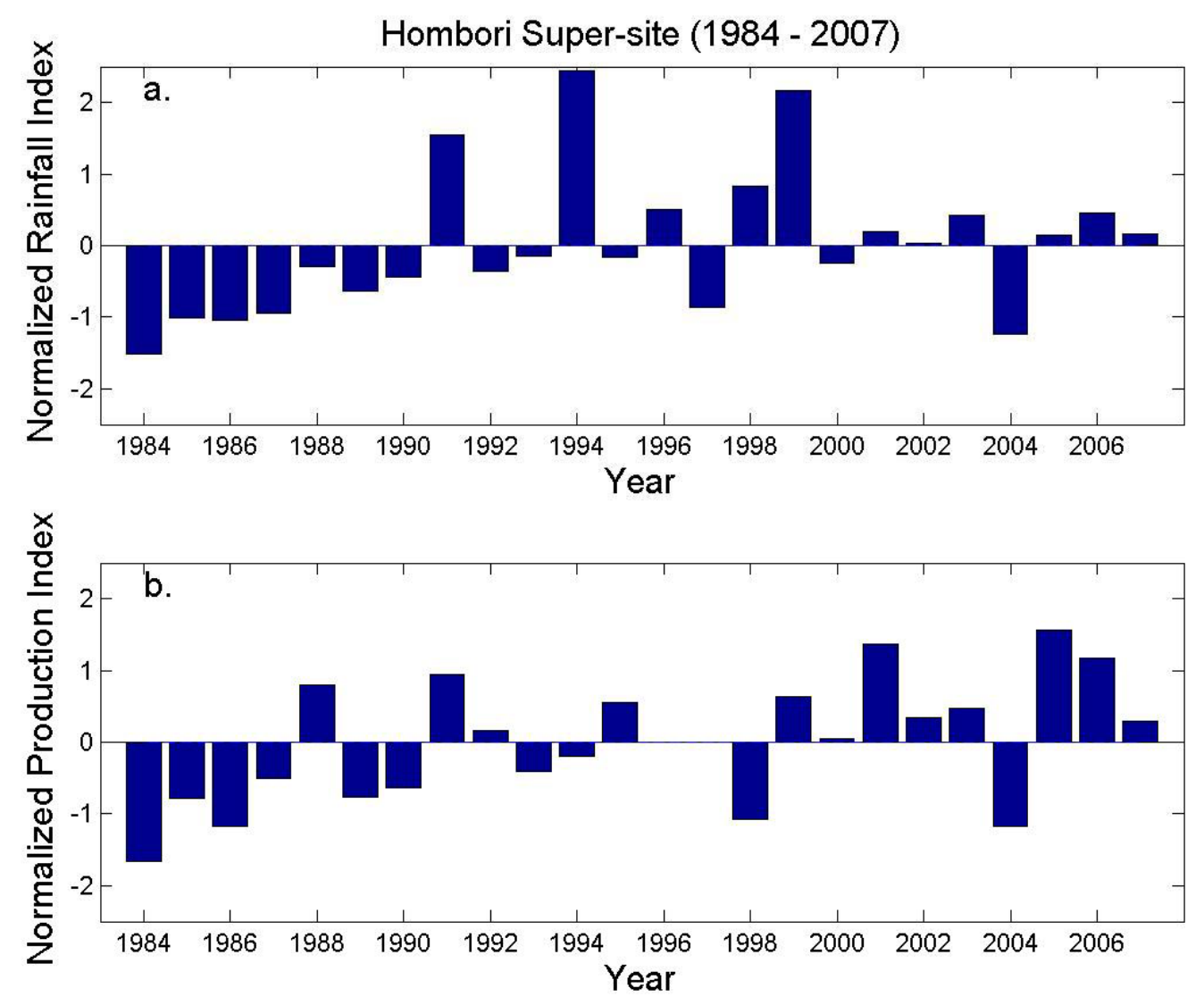